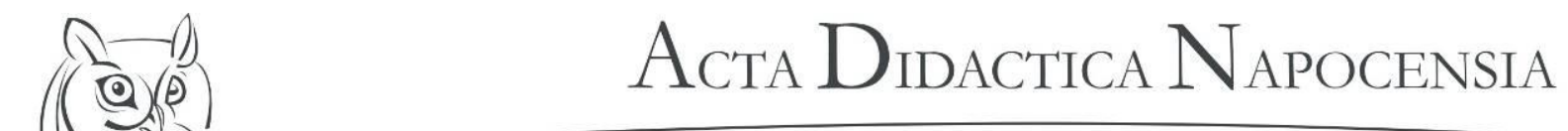

Volume 11, Number 2, 2018

\title{
Examination of Prospective Mathematics TEACHERS' SKILLS OF INTERPRETING ALGEBRAIC FORMULAE
}

\author{
Meltem Koçak, Yasin Soylu
}

\begin{abstract}
The aim of this study is to examine prospective mathematics teachers' skills of interpreting algebraic formulae at the student level. In this context, 84 prospective teachers studying in the senior class of the elementary mathematics teaching program of a university in Turkey constituted the participants of the study. In this study, the qualitative research approach was adopted, and the case study method was used. The data of the study were collected using the interpretation test that was prepared by the researchers and composed of formulae. The data obtained from the study were analyzed using the content and descriptive analysis techniques. As a result of the study, it was observed that prospective teachers did not examine the logic of the formulae, did not think too much about from where the formulae were obtained, and could not interpret the formulae at the student level. In the light of these results, it is suggested to raise awareness of the reasons underlying formulae in prospective teachers by providing the environments that improve prospective teachers' interpretation and reasoning skills on the formulae used in major area courses given during undergraduate education because the fact that prospective teachers comprehend the logic of the given formulae will have an effect on the teaching they will perform.
\end{abstract}

Key words: prospective teacher, interpretation, algebra formulae, mathematicial formulae.

\section{Introduction}

Mathematicians firstly define everything they want to examine. Then, they make judgements based on the definition they have accepted. The "Axioms System" is the most important of these judgements. The correctness of axioms systems is not proven, and the fact that they are real as a result of only alive impressions does not raise doubt. The axiom that is valid for a model or theory may not be valid for another model or theory. In this respect, the correctness of axioms is relative. This is followed by "Theorems, Formulae" (Baykul, 2014; Nasibov \& Kaçar, 2005). Theorems are the propositions that are accepted after their correctness is proven (Baykul, 2014). In mathematics, the formula is "a short algebraic expression used to show relationships between quantities. In other words, it is defined as the summarization of the relationships between quantities using mathematical symbols"(Albayrak, Iş1k \& İpek, 2005). Although it is possible to encounter many similar definitions related to mathematical formulae, the facts that they are short algebraic expressions that show basic relationships between quantities, they are the generalizations made using symbols, and they are a standard representation in which mathematical relationships are shown are the common points of all of them.

In mathematics, a concept forms the basis for the formation of many formulae (Işsksal, Kurt \& Doğan, Çakıroğlu, 2007). Therefore, the effective learning of basic concepts and rules in mathematics is of great importance. Nevertheless, the National Assessment of Educational Progress (NAEP) exam has shown that students cannot go beyond memorizing mathematical formulae and cannot learn formulae effectively. These results may be due to the excessive emphasis on formulae without being based on any conceptual basis. In this context, Van de Walle, Karp and Bay-Williams (2014), emphasized that formulae should be developed together with students even though exam systems make it possible to reach formulae during the exam for whatever reason it is and explained the reason for this by stating that "when students develop formulae, they reach the conceptual knowledge with respect to the 
conceptual structures and relations of formulae, and they are included in one of the real processes of performing mathematics".

With respect to this, in the renewed secondary school mathematics curriculum, the importance of being able to make students find out mathematical formulae and rules has been mentioned, and it has been emphasized to provide students with education that will enable them to establish relationships with the concepts behind the rules instead of making them memorize the rules directly. Accordingly, the aim of the new secondary school mathematics course curriculum is to gain mathematical knowledge, skills and attitudes that students may need in their life and subsequent education stages (MNE [Ministry of National Education], 2013). Accordingly, in the studies carried out by mathematics educators to solve the problems related to the learning and teaching of mathematics in schools, they have concluded that teachers should know mathematics better so that students can learn mathematics better (Ball, Thames \& Phelps, 2008).

When the mathematics teacher training system in the world is examined with respect to this, it is observed that prospective teachers primarily receive the information containing mathematical discussions and then work on the teaching of it. The reason for this is clear: no one can teach anything that they do not know. Therefore, prospective mathematics teachers should comprehend mathematics at a level they can teach (Philipp, Thanheiser \& Clement, 2002).

From this point of view, prospective mathematics teachers should firstly interpret mathematical formulae and should have knowledge about the fitness for purpose of the formulae they use to be able to teach mathematical formulae to their students. When the literature was examined in this context, studies on prospective teachers' skills of interpreting mathematical formulae were found to be limited (Arslan Kılcan, 2006; Koçak \& Soylu, 2017). It was also observed that most of the studies on the interpretation of mathematical formulae and rules were related to students (Barrantes \& Blanco, 2006; Battista \& Clements, 1996; Doğan, 2001; Olkun, 2003; Kamii \& Kysh, 2006; Tan Şişman \& Aksu 2009; Huang \& Witz, 2011; Olkun, Çelebi, Fidan, Engin \& Gökgün, 2014).

In this context, in this study, it was aimed to examine prospective elementary mathematics teachers' skills of interpreting algebraic formulae they use. This study is important both in terms of contributing to the literature and providing prospective teachers with an opportunity to interpret and reason the mathematical formulae they use.

\section{Method}

\subsection{Research Design}

In this study, the qualitative research approach was adopted, and the case study method was used. Qualitative research is a research approach in which the research process is flexible, and the data are examined in depth in this process and clearly expressed at the end of the study (Kohlbacher, 2006). In the case study method, it is aimed to reach the rich and mutually verifiable diversity of data by using multiple data collection tools (Yıldırım \& Şimşek, 2011). In this study, the qualitative data obtained by using several data collection tools together such as written statement, interview and document analysis were presented in a realistic and holistic manner. Therefore, the case study method was preferred in this study.

\subsection{Participants}

84 prospective elementary mathematics teachers studying in the senior class of the Elementary Mathematics Teaching Program of a university in Turkey constituted the participants of this study, which was carried out to determine prospective mathematics teachers' levels of interpreting algebraic formulae. The codes in the form of $T_{1}, T_{2}, T_{3}, \ldots, T_{84}$ were used instead of prospective teachers' real names in accordance with the ethical principles while explaining the results of the study. 


\subsection{Data Collection Tools}

In the study, a test consisting of algebraic formulae included in the secondary school mathematics curriculum, teachers' opinions and the formulae encountered in the notebooks of secondary school students were firstly prepared for the purpose of collecting data to determine prospective elementary mathematics teachers' levels of interpreting algebraic formulae. During the selection of the formulae given formula at the students' level and that the formulae would be those that were indicated to be found difficult by students in the literature (Bonotto, 2003; Fuys, Geddes, \& Tischler, 1988; Gökkurt, 2014; Olkun et al. 2014; Olkun, 2001; Tan Şişman \& Aksu, 2009). In this context, a literature review was performed, and a draft test consisting of 38 formulae was prepared. Two experts were asked for their suggestions regarding the draft test prepared, and the test was made final by reducing the number of formulae related to algebra to 6 . While the number of formulae in the draft test was reduced to 6 formulae, attention was paid to the fact that the formulae with similar properties related to the same subject would not coexist and to ensuring content validity. The formulae included in the interpretation test are presented in Table 1.

Table 1. Interpretation Test

\begin{tabular}{|c|c|c|c|c|}
\hline & Necessary & Unnecessary & Undecided & $\begin{array}{l}\text { Explain } \\
\text { the Reason }\end{array}$ \\
\hline $\begin{array}{l}\text { 1. } a b \text { and ba are two-digit numbers; } \\
a b+b a=11(a+b) ; a b-b a=9(a-b)\end{array}$ & & & & \\
\hline 2. $\quad(a+b+c)^{2}=a^{2}+b^{2}+c^{2}+2(a b+a c+b c)$ & & & & \\
\hline 3. $a^{3}-b^{3}=(a-b)\left(a^{2}+a b+b^{2}\right)$ & & & & \\
\hline 4. $0 !=1$ & & & & \\
\hline $\begin{array}{l}\text { 5. It is } \mathrm{a}^{0}=1 \text { if it is } \mathrm{a} \neq 0 \\
\text { 6. } \frac{a^{m}}{a^{n}}=a^{m-n}\end{array}$ & & & & \\
\hline
\end{tabular}

In the interpretation test presented in Table 1, prospective teachers were asked to explain whether it was necessary to give the relevant formulae to students along with their reasons. Here, the expectation from prospective teachers is that they can show how the relevant formula is obtained at the level of secondary school students $\left(5^{\text {th }}, 6^{\text {th }}, 7^{\text {th }}\right.$, and $8^{\text {th }}$ grade $)$, can explain the logic of the formula and accordingly state whether it is necessary to give this formula to students. Prospective teachers were given 20 minutes for this test, and attention was paid to the fact that they would not receive help from each other while answering the questions. After the written statements given by prospective teachers to this test were analyzed, prospective teachers' statements were examined in a more detailed manner by conducting face-to-face interviews with prospective teachers who gave incomprehensible or superficial answers to get more in-depth information. Thus, it was possible to examine all details of prospective teachers' answers.

\subsection{Data Analysis}

The descriptive analysis and content analysis techniques were used in the analysis of the data obtained from the interpretation test that was prepared for the skills of interpreting algebraic formulae of prospective elementary mathematics teachers. In this test, prospective teachers were asked to explain whether it was necessary to give the formulae included in the form to students during the mathematics teaching process along with their reasons. Here, the answer expected from prospective teachers is that they explain the reason as to whether the relevant formula should be given to students by associating it with the logical reason behind the formula or with other mathematical formulae they know.

When the data obtained as a result of the pilot study were examined, it was observed that some prospective teachers could obtain the relevant formula based on a logical reason or by associating it with 
appropriate mathematical formulae as it was expected, and they stated that it was necessary or unnecessary to give the formula to students depending on the difficulty of this process. The reasons of prospective teachers who gave answers in this way were included in the correct group. Similarly, it was observed that some prospective teachers, who could explain the logical reason of the formula or could obtain the relevant formula with appropriate mathematical formulae in the process of interpreting the given formula, decided on whether the relevant formula should be given to students without caring about the difficulty or easiness of the process of obtaining the formula. The reasons of prospective teachers who gave answers in this way were included in the wrong group. In addition to this, the answers of prospective teachers who could not make any instructive or logical explanation with respect to how the formula could be derived and who made explanations only by putting forward reasons such as practicality and time while explaining the reason as to whether it was necessary to give the relevant formula to students were also included in the wrong group. On the other hand, when prospective teachers' answers were examined, it was observed that the answers of some prospective teachers could not be included either in the correct group or in the wrong group. The reasons of prospective teachers who gave answers in this way were included in the Partially Correct A group. Similarly, it was also observed that some prospective teachers' explanations in which they explained the reason whether it was necessary to give the relevant formula to students, mainly included correct statements as well as wrong statements. Therefore, the answers of these prospective teachers could not be included in the wrong group, and they were included in the Partially Correct B group, which is a group close to wrong. It was also observed that some prospective teachers did not explain their reason as to whether it was necessary to give the relevant formula to students and that some of them were undecided as to whether it was necessary to give the relevant formula to students. The following codes were created by the researcher and an expert by considering all of these, and prospective teachers' answers were analyzed according to these codes.

Necessary/Unnecessary/Undecided and Correct Reason; The answers in which it was stated that it was necessary or unnecessary to give the relevant formula to students based on the logical reason underlying the formula or by associating it with appropriate mathematical formulae and depending on the difficulty of this process.

Necessary/Unnecessary/Undecided and Partially Correct Reason A; The answers in which the explanations about the logical reason underlying the relevant formula are not exactly correct but mostly have the correct content.

Necessary/Unnecessary/Undecided and Partially Correct Reason B; The answers in which the explanations about the logical reason underlying the relevant formula are not exactly wrong but mostly have the wrong content.

Necessary/Unnecessary/Undecided and Incorectly Reason; The answers in which the explanations about the logical reason underlying the relevant formula are wrong or the answers in which it was stated that it was necessary or unnecessary to give the relevant formula to students without considering the process of obtaining the formula.

Necessary/Unnecessary/Undecided and Unexplained Reason; The answers in which no explanation was made for the logical reason underlying the relevant formula.

Necessary: It is necessary to give the relevant formula to students.

Unnecessary: It is unnecessary to give the relevant formula to students, the student himself/herself can easily find out the formula.

Undecided: Undecided whether it was necessary to give the relevant formula to students. 


\section{Findings and Interpretation}

In the test that was applied to determine at what levels prospective teachers' skills of interpreting algebraic formulae and establishing relationships between these formulae were, prospective teachers were asked to explain whether it was necessary to give the relevant formulae to students along with their reasons. The codes were created by analyzing the written answers of prospective teachers using the descriptive analysis technique, and the frequency and percentage tables are presented according to these codes.

\subsection{Findings and Interpretation on the First Question}

In the first question, prospective teachers were asked to explain whether it was necessary to give the formula given in the form of

$a b$ and ba are two-digit numbers; $a b+b a=11(a+b) ; a b-b a=9(a-b)$

to students as a new formula along with their reasons. The code, frequency and percentages related to the answers given by prospective teachers to the first question are presented in Table 2 .

Table 2 Categories and Codes for the First Question

\begin{tabular}{|l|c|c|c|c|c|c|c|c|c|c|c|c|}
\hline \multirow{2}{*}{ Codes } & \multicolumn{2}{|c|}{ Correct } & \multicolumn{2}{|l|}{$\begin{array}{l}\text { Partially } \\
\text { Correct A }\end{array}$} & \multicolumn{2}{|c|}{$\begin{array}{l}\text { Partially } \\
\text { Correct B }\end{array}$} & \multicolumn{2}{l|}{ Incorrect } & \multicolumn{2}{|c|}{ Unexplained } & \multicolumn{2}{c|}{ Total } \\
\cline { 2 - 13 } & $\mathrm{f}$ & $\%$ & $\mathrm{f}$ & $\%$ & $\mathrm{f}$ & $\%$ & $\mathrm{f}$ & $\%$ & $\mathrm{f}$ & $\%$ & $\mathrm{f}$ & $\%$ \\
\hline $\begin{array}{l}\text { The necessity } \\
\text { reason of formula }\end{array}$ & 2 & $2 \%$ & 1 & $1 \%$ & 1 & $1 \%$ & 6 & $7 \%$ & - & - & 10 & $12 \%$ \\
\hline $\begin{array}{l}\text { The unnecessity } \\
\text { reason of formula }\end{array}$ & 61 & $73 \%$ & 10 & $11 \%$ & 2 & $2 \%$ & 1 & $1 \%$ & - & - & 74 & $88 \%$ \\
\hline $\begin{array}{l}\text { Undecided and the } \\
\text { reason }\end{array}$ & - & - & - & - & - & - & - & - & - & - & - & - \\
\hline
\end{tabular}

When Table 2 is examined, it is observed that $74(88 \%)$ prospective teachers argue that it is unnecessary to give the relevant formula to students while $10(11 \%)$ prospective teachers argue that it is necessary to give this formula to students. When prospective teachers were asked for their reasons as to whether it was necessary to give this formula to students, while 63 (75\%) prospective teachers could correctly explain the reason why they thought so, 14 (15\%) prospective teachers partially explained it correctly, and $7(8 \%)$ prospective teachers made a incorrectly explanation. When prospective teachers' answers were examined, most of the prospective teachers stated that it was unnecessary to give this formula to students since they could easily obtain this formula by performing the digit analysis. In other words, the vast majority of the prospective teachers who thought that it was unnecessary to give the formula could make a correct explanation by associating its reason with the logical reason underlying the given formula. On the other hand, some prospective teachers still argued that it was necessary to make students memorize this formula although they could correctly explain the logical reason for the given formula and easily obtain the formula. The explanation of $\mathrm{T}_{33}$ among these prospective teachers is presented in Figure 1.

When Figure 1 is examined, it is observed that this formula given could be easily obtained. Nevertheless, $\mathrm{T}_{33}$ thought that it was necessary to give the formula to students. It was observed that there were also few prospective teachers who could not obtain the formula even though it was so easy to obtain the formula (see Figure 1), could not explain the logical reason underlying the formula and could not make any instructive explanation. The explanation of $\mathrm{T}_{74}$ among these prospective teachers is presented in Figure 2. 


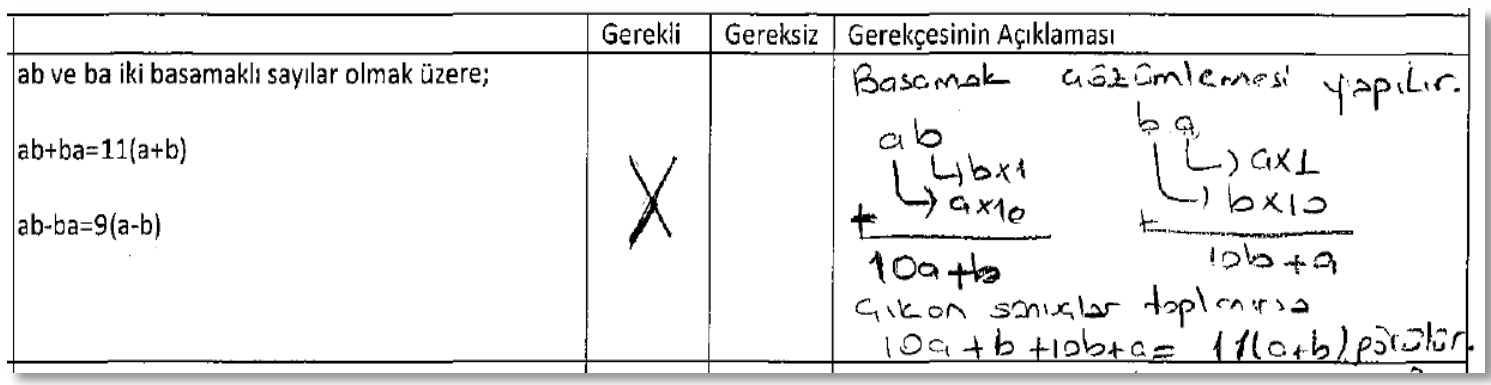

*Digit analysis is done.....the results are summed

Figure 1. Explanation of prospective teacher $T_{33}$ for the first question

\begin{tabular}{|c|c|c|c|}
\hline & Gerekii & Gereksiz & Gerekçesinin Açıklaması \\
\hline $\begin{array}{l}a b \text { ve ba iki basamaklı sayılar olmak üzere; } \\
a b+b a=11(a+b) \\
a b-b a=9(a-b)\end{array}$ & & & 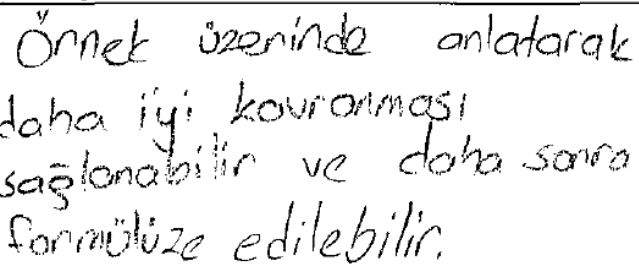 \\
\hline
\end{tabular}

*A better understand can be ensure by explaining on the example and can later formulated.

Figure 2. Explanation of prospective teacher $T_{74}$ for the first question

When Figure 2 was examined, it was observed that prospective teacher $\mathrm{T}_{74}$ could not make any explanation for the logical meaning of this formula given. Furthermore, it is observed that this prospective teacher stated that he would teach the given formula through the example and adopted teaching that was entirely focused on learning by heart. An interview was conducted with this prospective teacher to see in more detail what kinds of examples he would use during his teaching and how he would use them. The dialogue between the prospective teacher and the researcher during the interview is exactly given below.

Researcher: Can you tell the explanation you made for the first question in a more detailed manner?

T74: Here, in fact, you know, teacher, for example, we decompose into digits through the numbers $91+19$. For example, teacher, let's suppose that the numbers are 91 and 19. Teachers, if I write number 91 as $9 \cdot 10+1+1 \cdot 10+9$, it becomes $10(10)$ if we put it into parenthesis 10 , if we put the other side into parenthesis.. hmmm. Teacher, I mean I usually use this way while solving questions, but now I have not been able to decompose into digits."

Researcher: So, don't you use this formula while solving the questions given in this way?

T74: Teacher, I perform addition by decomposing into digits, not as a formula. I mean, for example, if I show through the example.

we will write $92+29=10 \cdot 9+1 \cdot 2+2 \cdot 10+9 \cdot 1$. if we put it into parenthesis 10 ;

$$
\begin{aligned}
& =10(9+2)+1(9+2) \quad \text { and then if we put it into parenthesis 11, from here; } \\
& =11(11)=121
\end{aligned}
$$

For example, I make students solve it with minus sign, then, I reach generalization through examples in this way.

Researcher: Well then, why do you think this formula should be given to students?

$T_{74}$ : I mean, I think that I can reinforce this with examples and then I can give the formula so that they can use this formula immediately when they see a question asked in this way. In this way, time is saved. 
When the explanations of prospective teacher $\mathrm{T}_{74}$ were examined, it was observed that this prospective teacher could perform the given formula using a specific value but could not put into general expressions with the help of the digit analysis. Similarly to prospective teacher $\mathrm{T}_{74}$, it was observed that two prospective teachers attempted to explain the logical reason underlying the formula given in the first question by giving a value. The explanations of $T_{71}$ and $T_{7}$ among these prospective teachers are presented in Figure 3 and Figure 4.

\begin{tabular}{|c|c|c|c|}
\hline & Gerekli & Gereksiz & Gerekçesinin Açıklaması \\
\hline $\begin{array}{l}a b \text { ve ba iki basamaklı sayılar olmak üzere; } \\
a b+b a=11(a+b) \\
a b-b a=9(a-b)\end{array}$ & & & 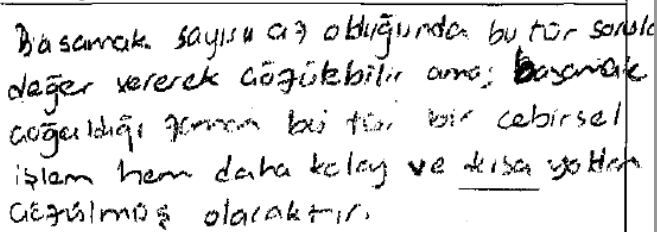 \\
\hline
\end{tabular}

* Since the number of steps is small, such questions can be solved by giving a value. However, when the number of steps increases, such algebraic operation will be solved both more easily and in a shorter way.

Figure 3 Explanation of prospective teacher $T_{71}$ for the first question

\begin{tabular}{|c|c|c|c|}
\hline & Gerekli & Gereksiz & Gerekçesinin Açıklaması \\
\hline $\begin{array}{l}\text { ab ve ba iki basamaklı sayılar olmak üzere; } \\
a b+b a=11(a+b) \\
a b-b a=9(a-b)\end{array}$ & & & 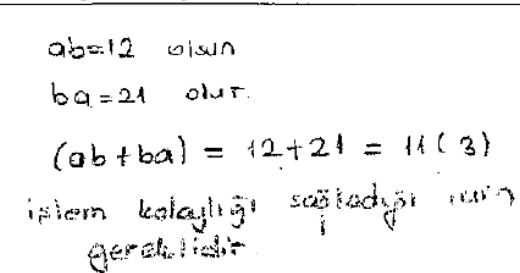 \\
\hline
\end{tabular}

"It is necessary for ease of operation

Figure 4. Explanation of prospective teacher $T_{7}$ for the first question

When the answers given by prospective teachers $T_{71}$ and $T_{7}$ were examined, it was observed that they applied the formula while making the deduction of the given formula. From this point of view, it can be said that prospective teachers could not explain the logical reason for the given formula and therefore could not interpret the formula. It is remarkable that these prospective teachers studying in the senior class of the mathematics teaching program could not interpret a formula that can be obtained so easily and could not learn it conceptually.

In conclusion, it was observed that most of the prospective teachers were successful in terms of interpreting the given formula with respect to the digit analysis, but there were also few prospective teachers who could not interpret the formula. Accordingly, the vast majority of the prospective teachers (73\%) could explain that it was unnecessary to give the formula given in the first question to students by putting forward a correct reason. However, in addition to this, it was also observed that there were prospective teachers $(11 \%)$ who stated that it was necessary to give the relevant formula that can be obtained so easily to students.

\subsection{Findings and Interpretation on the Second Question}

In the second question, regarding the identities, prospective teachers were asked to explain whether it was necessary to give the following formula

$$
(a+b+c)^{2}=a^{2}+b^{2}+c^{2}+2(a b+a c+b c)
$$


to students as a new formula along with their reasons. The code, frequency and percentages related to the answers given by prospective teachers to the second question are presented in Table 3 .

Table 3. Categories and Codes for the Second Question

\begin{tabular}{|c|c|c|c|c|c|c|c|c|c|c|c|c|}
\hline \multirow{2}{*}{$\begin{array}{l}\text { Codes } \\
\text { Categories }\end{array}$} & \multicolumn{2}{|c|}{ Correct } & \multicolumn{2}{|c|}{$\begin{array}{l}\text { Partially } \\
\text { Correct A }\end{array}$} & \multicolumn{2}{|c|}{$\begin{array}{l}\text { Partially } \\
\text { Correct B }\end{array}$} & \multicolumn{2}{|c|}{ Incorrect } & \multicolumn{2}{|c|}{ Unexplained } & \multicolumn{2}{|c|}{ Total } \\
\hline & $\mathrm{f}$ & $\%$ & $\mathrm{f}$ & $\%$ & $\mathrm{f}$ & $\%$ & $\mathrm{f}$ & $\%$ & $\mathrm{f}$ & $\%$ & $\mathrm{f}$ & $\%$ \\
\hline $\begin{array}{l}\text { The necessity reason of } \\
\text { formula }\end{array}$ & 16 & $19 \%$ & - & - & 1 & $1 \%$ & 13 & $15 \%$ & 2 & $2 \%$ & 32 & $\begin{array}{l}38 \\
\%\end{array}$ \\
\hline $\begin{array}{l}\text { The unnecessity reason } \\
\text { of formula }\end{array}$ & 40 & $48 \%$ & 4 & $5 \%$ & 2 & $2 \%$ & 5 & $6 \%$ & 1 & $1 \%$ & 52 & $\begin{array}{l}62 \\
\%\end{array}$ \\
\hline $\begin{array}{l}\text { Undecided and the } \\
\text { reason }\end{array}$ & - & - & - & - & - & - & - & - & - & - & - & - \\
\hline
\end{tabular}

When Table 3 is examined, $52(62 \%)$ prospective teachers argued that it was unnecessary to give this formula to students while $32(38 \%)$ prospective teachers argued that this formula should be given to students. When prospective teachers were asked for their reasons as to whether it was necessary to give this formula to students, while $56(67 \%)$ prospective teachers could correctly explain the reason, 7 (8\%) prospective teachers partially explained it correctly, 18 (21\%) prospective teachers made a wrong explanation, and $3(3 \%)$ prospective teachers did not make any explanation.

When prospective teachers' answers to the second question were examined, it was observed that prospective teachers could easily obtain the given formula usually based on the

$$
(a+b+c)^{2}=a^{2}+b^{2}+c^{2}+2(a b+a c+b c)
$$

formula, and therefore they argued that it was unnecessary to give this formula to students as a new formula. On the other hand, it was observed that there were also prospective teachers who explained how the formula was obtained in a similar way but still thought that it was necessary to give this formula to students as a new formula. The explanation of $\mathrm{T}_{6}$ among these prospective teachers is presented in Figure 5.

\begin{tabular}{|c|c|c|c|}
\hline & Gerekli & Gereksiz & Gerekçesinin Açıklaması \\
\hline$(a+b+c)^{2}=a^{2}+b^{2}+c^{2}+2(a b+a c+b c)$ & & & 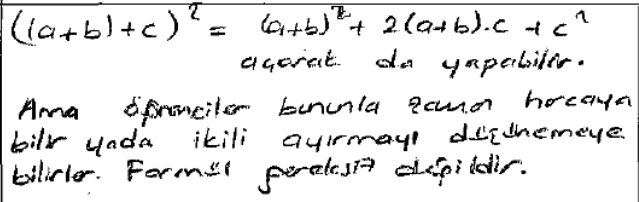 \\
\hline
\end{tabular}

*Students may waste their time with this or may not be able to think of binary division. The formula is not unnecessary.

Figure 5. Explanation of prospective teacher $T_{6}$ for the second question

When Figure 5 is examined, it is observed that prospective teacher $T_{6}$ argued that it was necessary to give this formula to students for the reason that students should not spend extra time although he could easily obtain the given formula. However, the formula given in the second question is a complex and long formula. Therefore, the memorization of this formula actually seems more difficult and timeconsuming. Furthermore, when it is considered that there are dozens of perfect square formulae in mathematics, the fact that students interpret and obtain the formulae that they can easily obtain through their previous learning, as it is seen in Figure 5, instead of memorizing them seems easier and less timeconsuming than trying to remember the formula. In this context, it can be said that the reason put forward by the prospective teacher is not a correct reason. 
When other prospective teachers' answers to the second question were examined, it was observed that some of the prospective teachers, who argued that it was unnecessary to give the relevant formula to students, could not explain the reason why they thought so clearly enough and could not make any instructive explanation. The explanation of $\mathrm{T}_{8}$ among these prospective teachers is presented in Figure 6.

\begin{tabular}{|c|c|c|c|}
\hline & Gerekli & Gereksiz & Gerekçesinin Açıklaması \\
\hline$(a+b+c)^{2}=a^{2}+b^{2}+c^{2}+2(a b+a c+b c)$ & & $x$ & 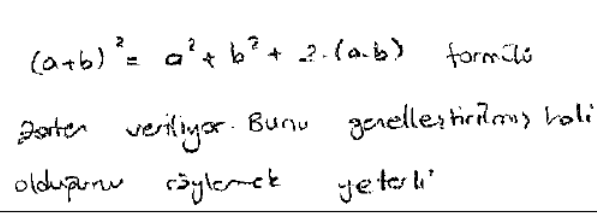 \\
\hline
\end{tabular}

${ }^{*}(a+b)^{2}=a^{2}+b^{2}+2 a b$ formula is already given. It is sufficient to say that it is the generalized form.

Figure 6. Explanation of prospective teacher $T_{8}$ for the second question

When Figure 6 was examined, it was observed that prospective teacher $\mathrm{T}_{8}$ made a quite superficial explanation and did not obtain the desired formula. However, it is expected from prospective teachers to obtain the formula by performing the application of their explanation and thus to show the logic of the formula. In this context, the explanation of another prospective teacher who argued that it was unnecessary to give the relevant formula to students by heart is presented in Figure 7.

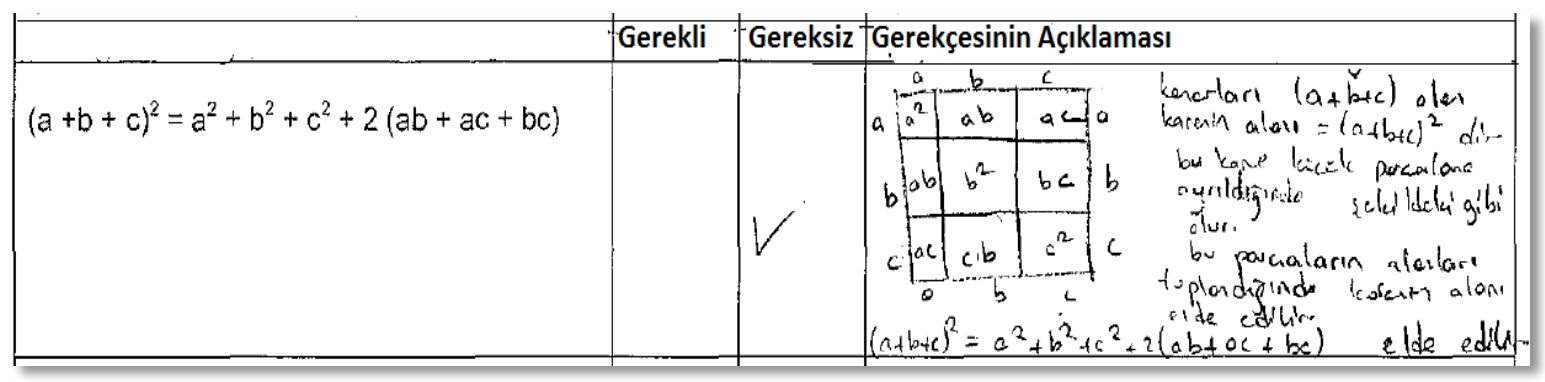

*The area of a square with side $(a+b+c)$ is $(a+b+c)^{2}$. When this square is divided into small pieces, it becomes like in the figure. When the areas of these pieces are added, the area of the square is obtained.

Figure 7. Explanation of prospective teacher $T_{77}$ for the second question

As it is seen in Figure 7, prospective teacher $\mathrm{T}_{77}$ could correctly explain the logical reason underlying the formula and could obtain the formula. However, it seems quite time-consuming and troublesome for students to draw a square in this way at each time and to be able to obtain this formula based on the area of the square. In this context, it is expected from prospective teachers to be able to show the relevant formula in a way that students can easily understand and apply it if they argue that it is unnecessary to give that formula to students. In other words, the method of obtaining the formula is expected to be practical and easily accessible. In addition to these, prospective teachers should consider the misconceptions while telling or explaining how a formula is obtained and should prefer to perform teaching that does not lead to misconceptions. With respect to this, when prospective teachers' explanations for the second question are examined, it is observed that the explanations of some prospective teachers as to whether it is necessary to give the given formula to students may lead to misconceptions among students. The explanation of $\mathrm{T}_{60}$ among these prospective teachers is presented in Figure 8. 


\begin{tabular}{|c|c|c|c|}
\hline & Gerekli & Gereksiz & Gerekçesinin Açıklaması \\
\hline$(a+b+c)^{2}=a^{2}+b^{2}+c^{2}+2(a b+a c+b c)$ & & & 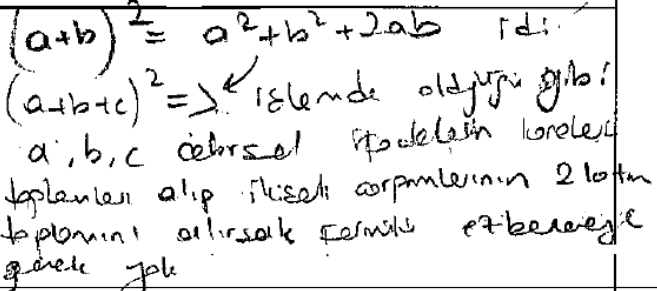 \\
\hline
\end{tabular}

$*(a+b+c)=>$ is in the operation, it is not necessary to memorize the formula if we take the sum of the squares of the algebraic expression $a, b, c$ and take the sum of the double of the binary multiplication.

Figure 8. Explanation of prospective teacher $T_{60}$ for the second question

As it is seen in Figure 8, prospective teacher $\mathrm{T}_{60}$ argued that it was unnecessary to give the formula and explained the reason why he thought so with a rule that was produced by himself without any logical basis. However, a student who generalizes this explanation may fall into a misconception in the form that it is $(a+b)^{3}=a^{3}+b^{3}+3 a b$ or $(a+b)^{4}=a^{4}+b^{4}+4 a b$. Therefore, it can be said that this prospective teacher could not interpret the given identity formula and learned it by heart.

In conclusion, it was observed that most of the prospective teachers were successful in terms of interpreting the given formula with respect to identities, but there were also few prospective teachers who could not interpret the formula. In this context, most (48\%) of the prospective teachers who thought that the given formula was unnecessary $(62 \%)$ correctly explained the reason why they thought so and could interpret the formula. Furthermore, it was observed that prospective teachers whose number cannot be underestimated (38\%) stated that this formula that could be easily obtained from the square of two terms should be given to students as a new formula.

\subsection{Findings and Interpretation on the Third Question}

In the third question, regarding the identities, prospective teachers were asked to explain whether it was necessary to give the following formula

$$
a^{3}-b^{3}=(a-b)\left(a^{2}+a b+b^{2}\right)
$$

to students as a new formula along with their reasons. The code, frequency and percentages related to the answers given by prospective teachers to the third question are presented in Table 4.

Table 4. Categories and Codes for the Third Question

\begin{tabular}{|l|c|c|c|c|c|c|c|c|c|c|c|c|}
\hline \multirow{2}{*}{ Codes } & \multicolumn{2}{|c|}{ Correctly } & \multicolumn{2}{|c|}{$\begin{array}{l}\text { Partially } \\
\text { Correct A }\end{array}$} & \multicolumn{2}{|c|}{$\begin{array}{l}\text { Partially } \\
\text { Correct B }\end{array}$} & \multicolumn{2}{c|}{ Incorrect } & \multicolumn{2}{l|}{ Unexplained } & \multicolumn{2}{c|}{ Total } \\
\cline { 2 - 13 } & $\mathrm{f}$ & $\%$ & $\mathrm{f}$ & $\%$ & $\mathrm{f}$ & $\%$ & $\mathrm{f}$ & $\%$ & $\mathrm{f}$ & $\%$ & $\mathrm{f}$ & $\%$ \\
\hline $\begin{array}{l}\text { The necessity } \\
\text { reason of formula }\end{array}$ & - & - & 13 & $15 \%$ & 3 & $3 \%$ & 34 & $40 \%$ & 18 & $21 \%$ & 68 & $81 \%$ \\
\hline $\begin{array}{l}\text { The unnecessity } \\
\text { reason of formula }\end{array}$ & - & - & 4 & $5 \%$ & 2 & $2 \%$ & 7 & $8 \%$ & - & - & 13 & $15 \%$ \\
\hline $\begin{array}{l}\text { Undecided and } \\
\text { the reason }\end{array}$ & - & - & - & - & - & - & - & - & 3 & $3 \%$ & 3 & $3 \%$ \\
\hline
\end{tabular}

As it is seen in Table 4, while $68(81 \%)$ prospective teachers argued that it was necessary to give this formula to students, $13(15 \%)$ prospective teachers argued that it was unnecessary to give this formula to students, and 3 prospective teachers did not make any explanation as to whether it was necessary to give this formula. When the answers of the prospective teachers explaining their reasons as to whether it was necessary to give this formula to students were examined, it was observed that none of the prospective teachers could correctly explain the reason why they thought so. Moreover, nearly half of the prospective teachers (48\%) wrongly explained the reason why they thought so, $22(25 \%)$ prospective 
teachers partially explained it correctly, and $21(24 \%)$ prospective teachers did not make any explanation.

When prospective teachers' answers to the third question were examined, it was observed that some of the prospective teachers stated that they could obtain the formula by taking a cube with the edge lengths of $b$ out of $a$ cube with the edge lengths of $a$ unit, but they argued that the formula should be memorized because they also had difficulty while maintaining the operation as well. The explanation of $\mathrm{T}_{82}$ among these prospective teachers is presented in Figure 9.

\begin{tabular}{|c|c|c|c|}
\hline & Gerekli & Gereksiz & Gerekçesinin Açıklaması \\
\hline 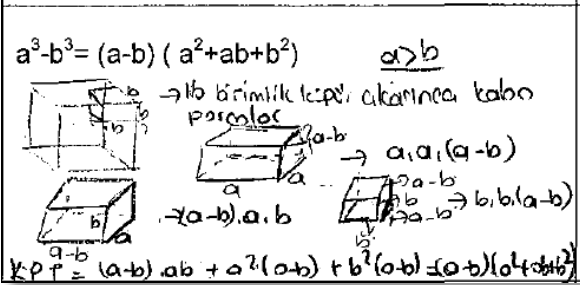 & $\uparrow$ & & 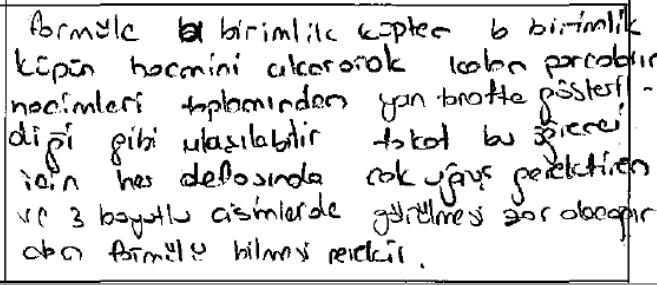 \\
\hline
\end{tabular}

*The formula can be attained by subtracting the volumes of the cubes with the side length of $b$ unit from the volumes of the cubes with the side length of a unit and summing the volumes of the remaining parts (as shown on this side). However, since this solution requires students to exert much effort and since it is difficult to imagine 3 dimensional objects, it is necessary to know the formula.

Figure 9. Explanation of prospective teacher $T_{82}$ for the third question

When Figure 9 is examined, it can be said that prospective teacher $\mathrm{T}_{82}$ could interpret this formula and explain the logical reason behind the formula. It is not surprising that a prospective teacher who attempted to obtain the formula in this way stated that it was necessary to give this formula to students because it is very difficult for a student to be able to make an explanation every time without using the formula. Similarly, some of the prospective teachers who could obtain the formula by using the expression $(\mathrm{a} \pm \mathrm{b})^{3}$ in binomial expansion argued that the formula should be memorized by stating that obtaining the formula requires long operations. The explanation of $\mathrm{T}_{62}$ among these prospective teachers is presented in Figure 10.

\begin{tabular}{|c|c|c|}
\hline & Gerekli & Gereksiz Gerekçesinin Açıklaması \\
\hline$a^{3}-b^{3}=(a-b)\left(a^{2}+a b+b^{2}\right)$ & $X$ & {$\left[\begin{array}{l}(a-b)^{3}=a^{3}-3 a^{2} b+3 a b^{2}-b^{3} \\
(a-b)^{3}=a^{3}-b^{3}-3 a b(a-b) \\
(a-b)\left((a-b)^{2}+3 a b\right)=a^{3}-b^{3} \\
(a-b)\left(a^{2}+b^{2}+a b\right)=a^{3}-b^{3} \\
\text { agrenci herzomon bu iskmi yomas } \\
\text { veun 2omon alir. }\end{array}\right.$} \\
\hline
\end{tabular}

*This solution requires students to exert much effort.

Figure 10. Explanation of prospective teacher $T_{62}$ for the third question

When Figure 10 is examined, it is observed that prospective teacher $\mathrm{T}_{62}$ could obtain the formula but thought that it was necessary to give the formula to students due to concern for time. Similarly to prospective teacher $\mathrm{T}_{62}$, the explanation of another prospective teacher $\mathrm{T}_{31}$ who thought that it was necessary to give the formula to students is presented in Figure 11. 


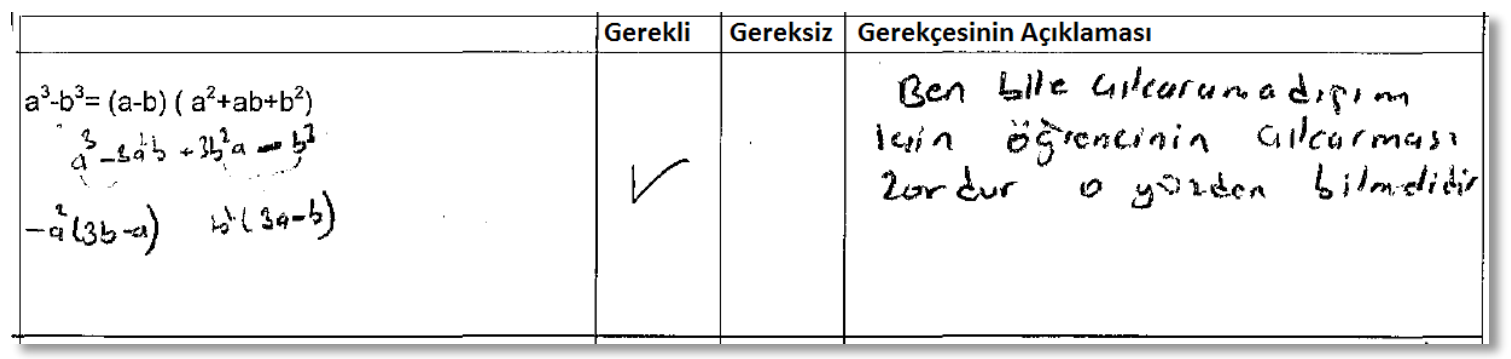

*Since even I cannot derive it, it is hard for a student to derive this formula.

Figure 11. Explanation of prospective teacher $T_{31}$ for the third question

When Figure 11 was examined, it was observed that prospective teacher $\mathrm{T}_{31}$ could not obtain and interpret the given formula, so he argued that the formula should be memorized. However, here, it is expected from the prospective teacher to make meaningful explanations about the acquisition of the formula and to indicate whether it is necessary or unnecessary to give the formula to students after establishing a mathematical relationship. When it is considered that this prospective teacher will probably work in schools as a mathematics teacher after a term, it is worrying that he could not interpret such a simple mathematical formula. The fact that the mistake made by the prospective teacher while explaining the logical reason for the given formula would lead to various misconceptions or learning difficulties is another similar worrying situation. The explanation of $\mathrm{T}_{30}$ among these prospective teachers is presented in Figure 12.

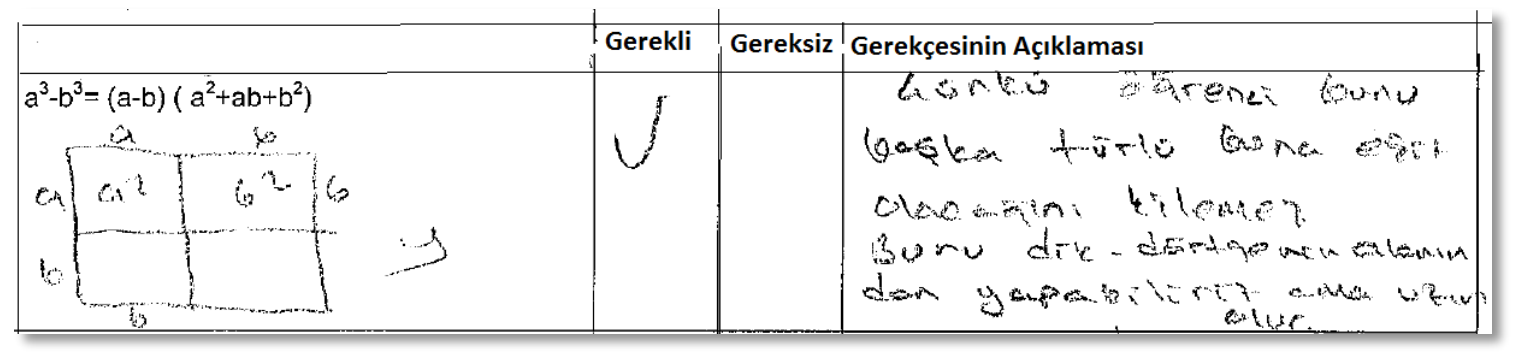

*We should give the formula because a student cannot know this formula otherwise. We can find this from the area of a rectangular, but it will take longer.

Figure 12. Explanation of prospective teacher $T_{30}$ for the third question

When Figure 12 is examined, as it is seen, the prospective teacher attempted to use the area of a rectangular region without considering the cube expression while explaining the logical reason for the given formula. This explanation made by the prospective teacher reveals the possibility that he may have a mistake or misconception caused by him. Unlike this prospective teacher, it was observed that another prospective teacher argued that the formula should be made memorized by students although he could explain how the formula could be obtained, the statement of his logical reason, and how the given formula could be taught. The explanation of this prospective teacher is presented in Figure 13.

When Figure 13 is examined, it is observed that prospective teacher $\mathrm{T}_{66}$ could easily obtain the given formula based on a general expression but thought that the formula should be given to students by heart. The data of the interview conducted with this prospective teacher to learn more deeply why this prospective teacher thought so are exactly presented below.

"Actually, I do not know why I have said that it is necessary to give the formula, here I can find it simply for $n=3$. But at that moment, I might have thought that the formula should be memorized because speed is important in exams like TEOG (transition from primary to secondary education). But now, I think it is unnecessary to give the given formula." 
When the explanation of the prospective teacher is examined, it is observed that he stated that it was unnecessary to give the formula to students as a new formula contrary to what he said in his written explanation. In this context, it was observed that the prospective teacher mentioned that speed is important in the exam system in our country with respect to why he gave another answer in his written statement.

In conclusion, it was observed that most of the prospective teachers could not interpret the given formula with respect to identities and therefore adopted the teaching of the formula by heart. The prospective teachers who stated that the formula should be memorized usually put forward the property of performing operations quickly as a requirement of our exam system as a reason for this. However, many formulae similar to this formula can be obtained in mathematics. Therefore, it is thought that it requires a longer and harder process for students to memorize all these formulae and apply them in the right place.

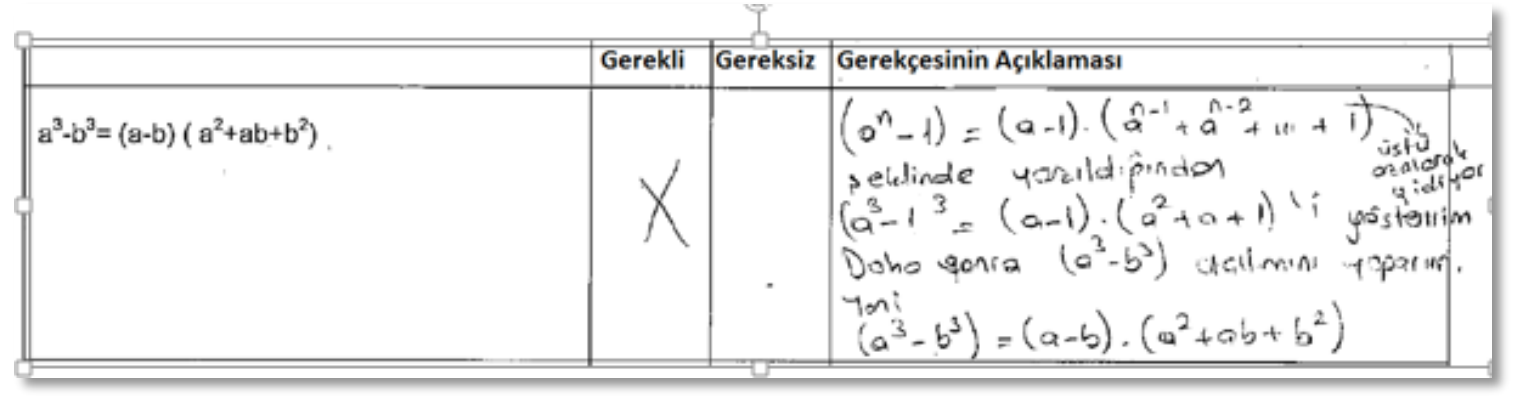

Figure 13. Explanation of prospective teacher $T_{66}$ for the third question

\subsection{Findings and Interpretation on the Fourth Question}

In the fourth question, prospective teachers were asked to explain whether it was necessary to give the

$$
0 !=1
$$

rule to students as a new formula along with their reasons. The code, frequency and percentages related to the answers given by prospective teachers to the fourth question are presented in Table 5 .

Table 5. Categories and Codes for the Fourth Question

\begin{tabular}{|l|c|c|c|c|c|c|c|c|c|c|c|c|}
\hline \multirow{2}{*}{ Codes } & \multicolumn{2}{|c|}{ Correctly } & \multicolumn{2}{|c|}{$\begin{array}{l}\text { Partially } \\
\text { Correct A }\end{array}$} & \multicolumn{2}{c|}{$\begin{array}{l}\text { Partially } \\
\text { Correct B }\end{array}$} & \multicolumn{2}{c|}{ Incorrect } & \multicolumn{2}{c|}{ Unexplained } & \multicolumn{2}{c|}{ Total } \\
\cline { 2 - 13 } & $\mathrm{f}$ & $\%$ & $\mathrm{f}$ & $\%$ & $\mathrm{f}$ & $\%$ & $\mathrm{f}$ & $\%$ & $\mathrm{f}$ & $\%$ & $\mathrm{f}$ & $\%$ \\
\hline $\begin{array}{l}\text { The necessity } \\
\text { reason of formula }\end{array}$ & 15 & $18 \%$ & 1 & $1 \%$ & 3 & $4 \%$ & 25 & $30 \%$ & 2 & $2 \%$ & 46 & $55 \%$ \\
\hline $\begin{array}{l}\text { The unnecessity } \\
\text { reason of formula }\end{array}$ & - & - & - & - & - & - & 35 & $42 \%$ & 1 & $1 \%$ & 36 & $43 \%$ \\
\hline $\begin{array}{l}\text { Undecided and the } \\
\text { reason }\end{array}$ & - & - & - & - & - & - & - & - & 2 & $2 \%$ & 2 & $2 \%$ \\
\hline
\end{tabular}

When Table 5 is examined, it is observed that while $36(43 \%)$ prospective teachers argued that it was unnecessary to give the relevant rule to students, $46(55 \%)$ prospective teachers argued that it was necessary to give the relevant rule to students, and $2(2 \%)$ prospective teachers were undecided as to whether it was necessary to give this rule to students. When prospective teachers were asked for their reasons as to whether it was necessary to give this rule to students, while $15(18 \%)$ prospective teachers could correctly explain the reason why they thought so, 4 (5\%) prospective teachers partially explained it correctly, $60(72 \%)$ prospective teachers wrongly explained their reasons, and $5(5 \%)$ prospective teachers did not make any explanation.

When prospective teachers' explanations for the fourth question were examined, it was observed that some of the prospective teachers argued that this rule was an acceptance without any educational basis, 
and therefore they thought that this rule should be directly made memorized by students. The explanation of $\mathrm{T}_{47}$ among these prospective teachers is presented in Figure 14.

\begin{tabular}{|c|c|c|c|}
\hline & Gerekli & Gereksiz & Gerekçesinin Açıklaması \\
\hline $0 !=1$ & $x$ & & 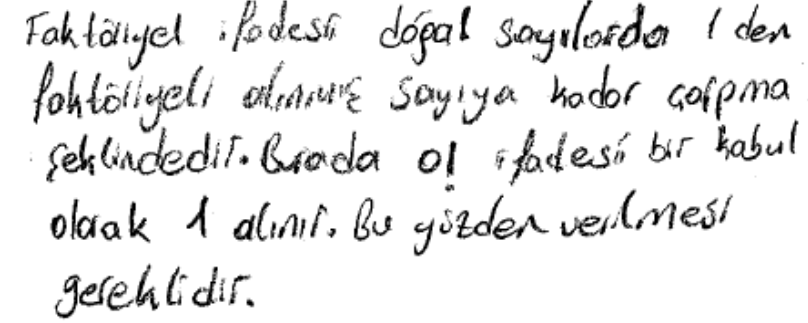 \\
\hline
\end{tabular}

*The factorial expression is in the form of multiplication until the number the factorial of which is taken from 1. Here 0! expression is taken as 1 as an agreement. For this reason, this rule should be given to students.

Figure 14. Explanation of prospective teacher $T_{47}$ for the fourth question

When Figure 14 is examined, it is observed that the prospective teacher could not interpret the given formula and stated that the concept of the factorial starts from 1 , so the fact that it is $0 !=1$ is just an acceptance. In this context, the fact that the prospective teacher stated that this formula should be made memorized as a new formula is a normal situation.

On the other hand, it was observed that some of the prospective teachers could interpret the given rule and could obtain the given rule by using the pattern, but they considered that it would be difficult for students to act every time in this way because of the fact that this acquisition process is long and troublesome. For this reason, it was observed that most of the prospective teachers who thought in this way argued that this rule should be given to students as a new rule, but how it is obtained should also be demonstrated. The explanation of $\mathrm{T}_{84}$ among these prospective teachers is presented in Figure 15.

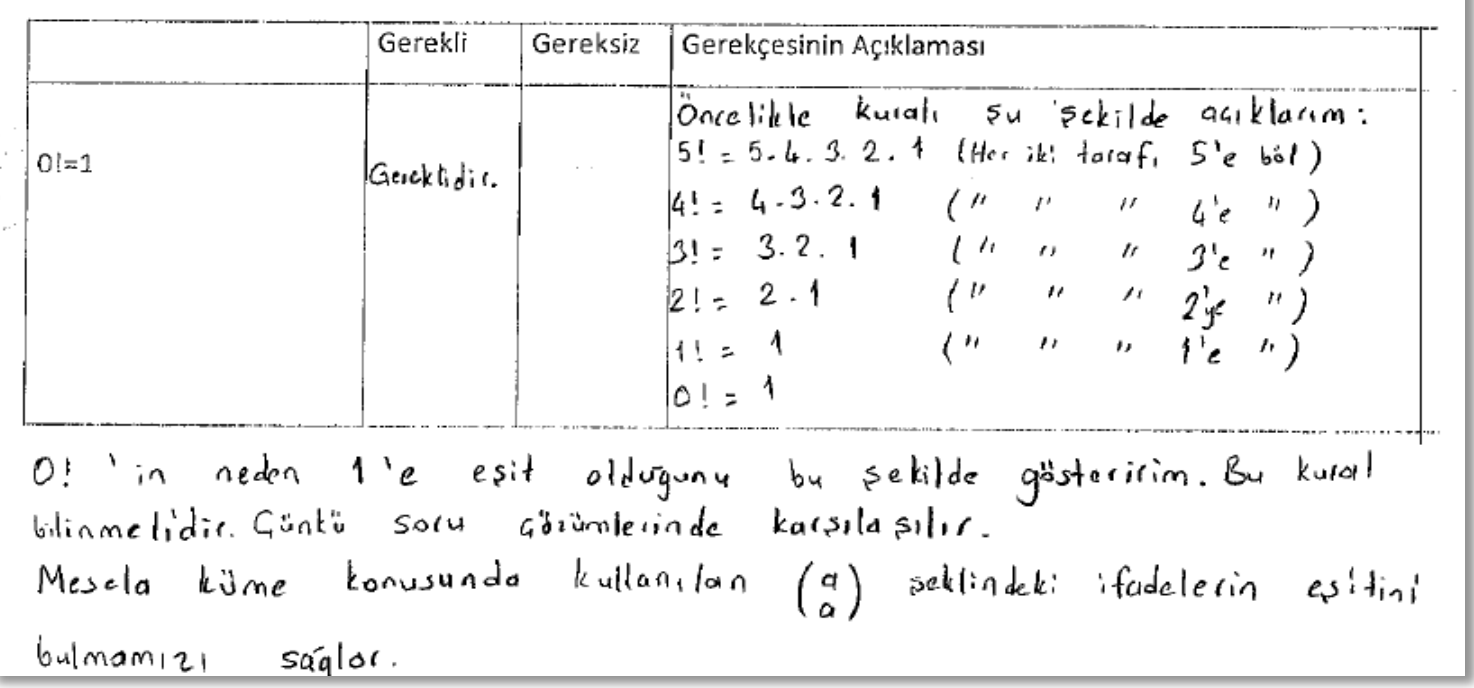

*I show why 0! is equal to 1 in this way. This rule should be known because we encounter with this in the question solutions. For example, it enables us to find the equal of the expressions as $\left(\begin{array}{l}a \\ a\end{array}\right)$ employed in the subject of clusters.

Figure 15. Explanation of prospective teacher $\mathrm{T}_{84}$ for the fourth question 
When Figure 15 is examined, it is observed that the prospective teacher could obtain the given rule in a way that students could understand by using the pattern and argued that this rule should be given to students in terms of practicality since the process is long. Similarly, it was observed that there were also few prospective teachers who could obtain the given rule with the help of the pattern but who thought that it was unnecessary to give this rule to students as a new rule without considering the length of the process.

In addition to these, the explanation of prospective teacher $\mathrm{T}_{52}$ who could also interpret the given rule and could show the rule using the properties of the factorial is presented in Figure 16.

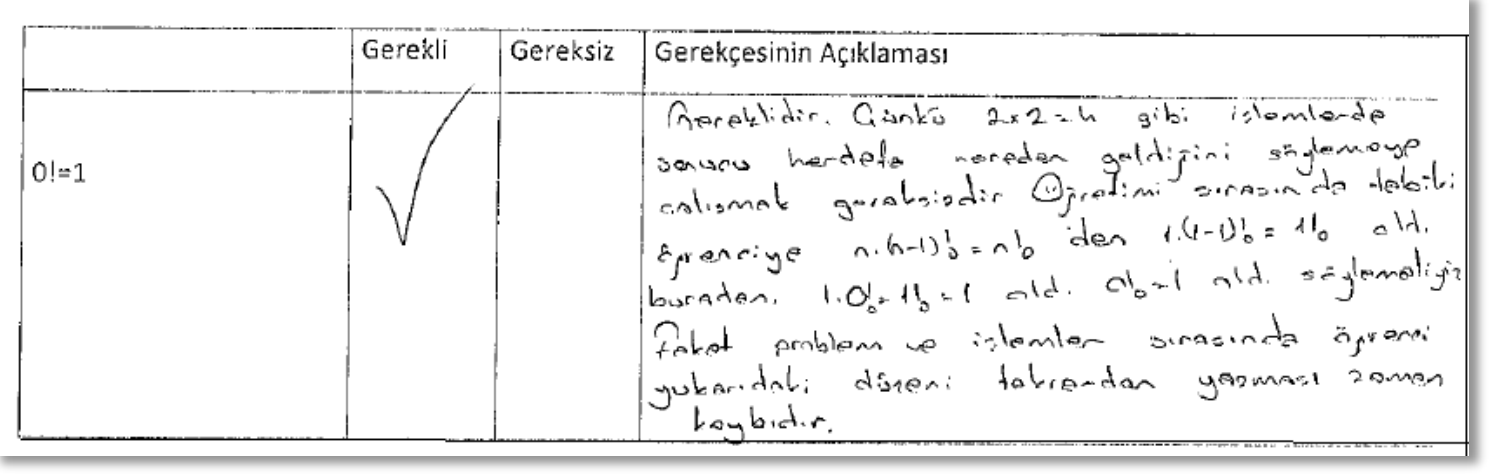

"The formula is necessary because it is meaningless to try to tell where the result comes from in operations such as $2 \cdot 2=4$. Of course, we have to tell that $n \cdot(n-1) !=n !, 1(1-1) !=1,1 \cdot 0 !=1,0 !=1$ while teaching. However, it is unnecessary for a student to rewrite the operation above in the course of problem and operations.

Figure 16. Explanation of prospective teacher $T_{52}$ for the fourth question

When Figure 16 was examined, it was observed that the prospective teacher made a correct explanation; nonetheless, he stated that it was necessary to give the given rule to students as a new rule in terms of practicality and concern for time.

In addition to all of these, it was mentioned above that there were also prospective teachers who made no explanation for the interpretation of the $0 !=1$ rule and were undecided as to whether it was necessary to give this rule to students. An interview was conducted with prospective teacher $T_{2}$ to see in more detail what this prospective teacher thought, and an attempt to find out why the prospective teacher did not make any explanation regarding the interpretation of this rule during this interview was made. The data of the interview conducted with this prospective teacher are exactly presented below.

"I had no idea about how this rule would be obtained during this application. After the application, I asked a friend. Actually, I had this solution in my mind, it did not come to my mind during the application for some reason. Now, we can say that it is $n !=n .(n-1) !$. when we write 1 instead of $n . .$. would we write 1 , yes we would write 1 . So, $1 !=0$ has become reverse for $n=1$, I suppose we would write for $n=0$. If we write $n=0 \ldots$ no. Why not if we write $n=1$, it is $1 !=0 !$ when we write $n=1$. From here, it becomes $0 !=1$. Yes, it is. It may be difficult to do this every time, so I think this rule should be given to students. However, the rule would be more permanent when this method is used while giving the rule."

When the prospective teacher's explanation was examined, it was observed that he could not fully internalize the $0 !=1$ rule and attempted to show how the rule was obtained by trying to remember a solution he had seen previously. It was also observed that the explanations of some prospective teachers who tried to explain the meaning of the given rule were not fully instructive and clear and could even lead to misconceptions among students. The explanation of $\mathrm{T}_{33}$ among these prospective teachers is presented in Figure 17. 


\begin{tabular}{|c|c|c|c|}
\hline & Gerekli & Gereksiz & Gerekçesinin Açıklaması \\
\hline $0 !=1$ & & X & 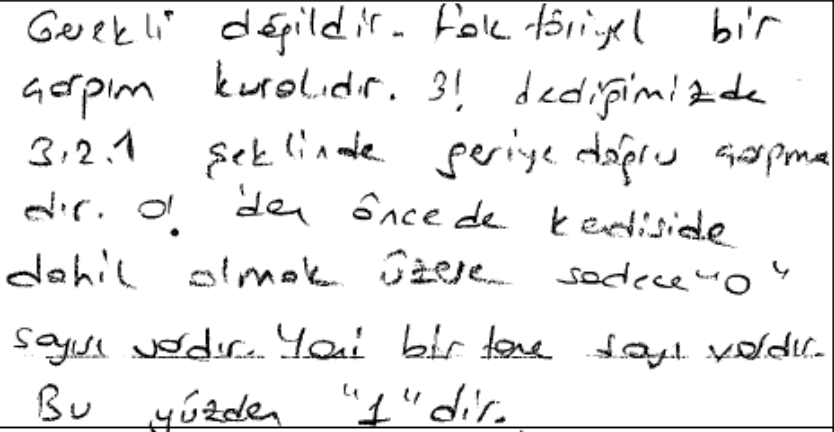 \\
\hline
\end{tabular}

*Not necessary. It is a factorial multiplication rule. In other words, what we call 3! is backwards multiplication in the form of 3.2.1. Before 0! there is only number 0 including itself. In other words, there is only one number, thus, $0 !=1$.

Figure 17. Explanation of prospective teacher $T_{33}$ for the fourth question

When Figure 17 was examined, it was observed that the prospective teacher mentioned that the concept of the factorial is to count backwards and stated that it was $0 !=1$ since there would be one number in 0 !. It is observed that this explanation made by the prospective teacher had no logical aspect. Moreover, an explanation made in this way may lead to a misconception that is formed by overgeneralization, such as $3 !=3$ and $4 !=4$, in students. Similar to prospective teacher $T_{33}$, it was observed that there were also other prospective teachers who could not fully interpret the logical reason of the given rule and therefore could not make correct explanations about how the rule could be obtained. The explanation of $\mathrm{T}_{74}$ among these prospective teachers is presented in Figure 18.

\begin{tabular}{|c|c|c|c|}
\hline & Gerekli & Gereksiz & Gerekçesinin Açıllaması \\
\hline $0 !=1$ & & & 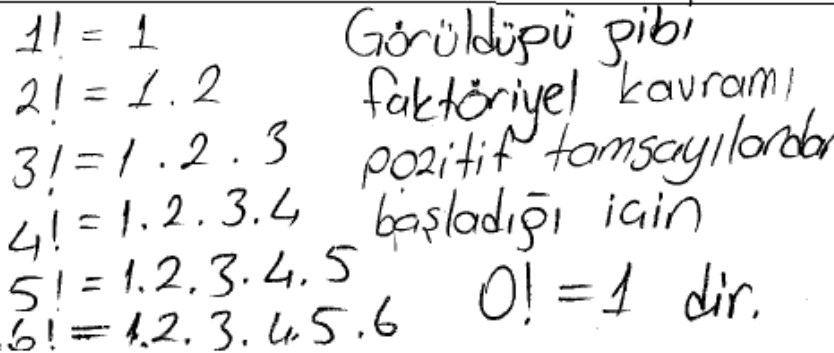 \\
\hline
\end{tabular}

*As it can be seen, since the concept of factorial starts at positive whole numbers, $0 !=1$.

Figure 18. Explanation of prospective teacher $T_{74}$ for the fourth question

When Figure 18 was examined, it was observed that the prospective teacher could not interpret the given rule and made a wrong explanation. Furthermore, it is observed that this explanation made by the prospective teacher may lead to wrong learning in students.

In conclusion, when prospective teachers' explanations for the fourth question were examined, it was observed that the prospective teachers who could interpret the $0 !=1$ rule correctly either benefited from the patterns or benefited from the property of the factorial. Moreover, it was observed that some prospective teachers made completely wrong explanations without any instructive aspect. It was also observed that prospective teachers mostly (55\%) stated that this rule should be given to students as a new formula. 


\subsection{Findings and Interpretation on the Fifth Question}

In the fifth question, prospective teachers were asked to explain whether it was necessary to give the $"$ it is $\mathrm{a}^{0}$ if it is $\mathrm{a} \neq 0$ "

rule to students as a new formula along with their reasons. The code, frequency and percentages related to the answers given by prospective teachers to the fifth question are presented in Table 6 .

Table 6. Categories and Codes for the Fifth Question

\begin{tabular}{|l|c|c|c|c|c|c|c|c|c|c|c|c|}
\hline \multirow{2}{*}{ Codes } & \multicolumn{2}{|l|}{ Correctly } & \multicolumn{2}{l|}{$\begin{array}{l}\text { Partially } \\
\text { Correct A }\end{array}$} & \multicolumn{2}{l|}{$\begin{array}{l}\text { Partially } \\
\text { Correct B }\end{array}$} & \multicolumn{2}{l|}{ Incorrect } & \multicolumn{2}{l|}{ Unexplained } & \multicolumn{2}{l|}{ Total } \\
\cline { 2 - 13 } & $\mathrm{f}$ & $\%$ & $\mathrm{f}$ & $\%$ & $\mathrm{f}$ & $\%$ & $\mathrm{f}$ & $\%$ & $\mathrm{f}$ & $\%$ & $\mathrm{f}$ & $\%$ \\
\hline $\begin{array}{l}\text { The necessity } \\
\text { reason of } \\
\text { formula }\end{array}$ & 1 & $1 \%$ & - & - & 16 & $19 \%$ & 18 & $21 \%$ & 8 & $10 \%$ & 43 & $51 \%$ \\
\hline $\begin{array}{l}\text { The } \\
\text { unnecessity } \\
\text { reason of } \\
\text { formula }\end{array}$ & - & - & - & - & - & - & 40 & $48 \%$ & - & - & 40 & $48 \%$ \\
\hline $\begin{array}{l}\text { Undecided and } \\
\text { the reason }\end{array}$ & - & - & - & - & - & - & - & - & 1 & $1 \%$ & 1 & $1 \%$ \\
\hline
\end{tabular}

When Table 6 was examined, it was observed that while a total of $40(48 \%)$ prospective teachers argued that it was unnecessary to give the relevant formula to students, $43(51 \%)$ prospective teachers argued that it was necessary to give the relevant formula to students, and 1 prospective teacher was undecided about whether the given formula was necessary and did not make any explanation. When prospective teachers' reasons are examined, it is observed all of the prospective teachers who argued that it was unnecessary to give the given formula to students wrongly explained the reasons why they thought so. When the answers of the prospective teachers who thought that it was necessary to give the given formula were examined, it was observed that 18 prospective teachers wrongly explained their reasons, 18 prospective teachers partially explained them correctly, and 8 prospective teachers did not make any explanation.

When prospective teachers' explanations were examined, it was observed that some of the prospective teachers who thought that it was unnecessary to give the given rule to students explained the reason why they thought so by using the properties of exponential expressions. The explanation of $\mathrm{T}_{77}$ among these prospective teachers is presented in Figure 19.

\begin{tabular}{|c|c|c|c|}
\hline & Gerekli & Gereksiz & Gerekçesinin Açıklaması \\
\hline$a \neq 0$ ise, $a^{0}=1$ dir. & & & $\begin{array}{l}\text { ornegn } \frac{a^{2}}{a^{2}} \text { yi ele alolime } \frac{a^{2}}{a^{2}}=a^{2} \cdot b^{-2} \\
a^{2}=\frac{a \cdot a}{2+a c} \quad a^{2}=\frac{a^{-1} \cdot a^{-1}}{2+a \cdot}=\frac{1}{a} \cdot \frac{1}{a} \\
a^{2} \cdot a^{-2}=a \cdot a \cdot a^{-1} \cdot a^{-1}=a \cdot \frac{1}{a} \cdot a \cdot \frac{1}{a}=1 \cdot 1=1 \mathrm{dir}\end{array}$ \\
\hline
\end{tabular}

Figure 19. Explanation of prospective teacher $\mathrm{T}_{77}$ for the fifth question

When Figure 19 is examined, it is observed that prospective teacher $\mathrm{T}_{77}$ could interpret and explain the given formula. It was also observed that the prospective teacher stated that it was unnecessary to give the formula to students as a new formula. This requires students to perform these operations every time to find the zero power of a number, which seems to be more difficult and more complex than knowing this formula by heart. For this reason, the reason put forward by this prospective teacher was classified 
under the partially correct category. Furthermore, the explanation of $\mathrm{T}_{74}$ among prospective teachers who stated that the given formula was unnecessary and explained the reason for this very similarly to $\mathrm{T}_{77}$ is presented in Figure 20.

\begin{tabular}{|c|c|c|c|}
\hline & Gerekli & Gereksiz & Gerekçesinin Açıklaması \\
\hline$a \neq 0$ ise, $a^{0}=1 \mathrm{dir}$. & & & inoti vonicse öprensi \\
\hline
\end{tabular}

Figure 20. Explanation of prospective teacher $T_{74}$ for the fifth question

When Figure 20 was examined, it was observed that the prospective teacher could interpret the formula and stated that it was unnecessary to give this formula to students as a new formula. During the interview, it was also observed that the prospective teacher stated that he would show the given formula to students in this way. However, when the secondary school mathematics course curriculum (2013) is examined, it is mentioned that the formula $\mathrm{a}^{0}$ should firstly be taught to be able to use the formula $\mathrm{a}^{\mathrm{m}-\mathrm{n}}$. Therefore, the prospective teacher should interpret this formula at the level that students can understand. The explanation of prospective teacher $\mathrm{T}_{50}$ who interpreted the given formula at the student level with his explanation and thought that it was unnecessary to give the given formula to students as a new formula is presented in Figure 21.

\begin{tabular}{|c|c|c|c|}
\hline & Gerekli & Gereksiz & Gerekçesinin Açıklaması \\
\hline$a \neq 0$ ise, $a^{0}=1$ dir. & & & 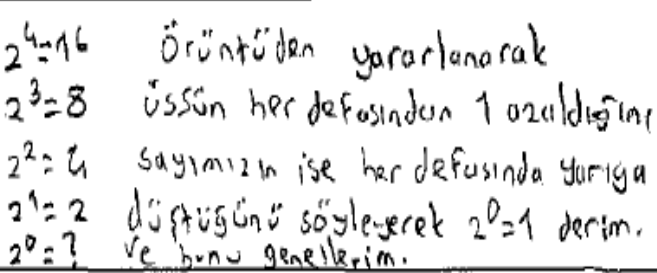 \\
\hline
\end{tabular}

*By making use of the pattern, I would say $2^{0}=1$, since the exponent decreases by 1 each time, and the number decreases by half each time, and I would generalize this.

Figure 21. Explanation of prospective teacher $T_{50}$ for the fifth question

When Figure 21 is examined, it is observed that prospective teacher $\mathrm{T}_{50}$ could interpret the given formula and could explain it in accordance with the students' level by using the pattern. However, when the explanation of the prospective teacher was examined, the fact that he stated that it was unnecessary to give the formula to students although he stated that he would reach generalization after showing this pattern was considered as a contradictory explanation. In this case, the reason of the prospective teacher was included in the partially correct category.

In addition to these, when prospective teachers' written answers were examined, it was observed that some prospective teachers thought that it was difficult to interpret the given formula at the student level, and therefore, they stated that there was no alternative other than making students memorize this formula. The explanation of $\mathrm{T}_{34}$ among these prospective teachers is presented in Figure 22. 


\begin{tabular}{|c|c|c|c|}
\hline & Gerekli & Gereksiz & Gerekçesinin Açıklaması \\
\hline$a \neq 0$ ise, $a^{0}=1$ dir. & & & 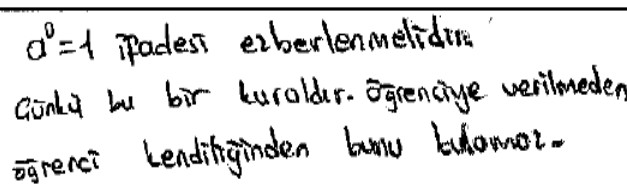 \\
\hline
\end{tabular}

${ }^{*} a^{0}=1$ formulae should be memorized because this is a rule. A student cannot find this rule on his own.

Figure 22. Explanation of prospective teacher $T_{34}$ for the fifth question

When Figure 22 was examined, it was observed that prospective teacher $\mathrm{T}_{34}$ could not make any explanation about how the given rule was obtained and its meaning and argued that the formula should be made memorized by students. Similarly, it was observed that there were prospective teachers who argued that the given rule should be made memorized by students and that these prospective teachers could not make sufficiently clear and instructive explanations. The explanation of $\mathrm{T}_{56}$ among these prospective teachers is presented in Figure 23.

\begin{tabular}{|c|c|c|c|}
\hline & Gerekli & Gereksiz & Gerekçesinin Açıklaması \\
\hline$a \neq 0$ ise, $a^{0}=1$ dir. & $\sqrt{ }$ & & 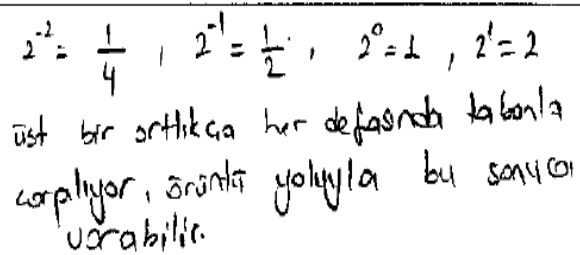 \\
\hline
\end{tabular}

*As the exponent increases, it is multiplied by the base each time. The formula can be found through the pattern

Figure 23. Explanation of prospective teacher $\mathrm{T}_{56}$ for the fifth question

When Figure 23 is examined, it is observed that the explanation of "as the exponent increases, it is multiplied by the base every time" made by prospective teacher $\mathrm{T}_{56}$ has no correctness and may also cause students to learn by heart and to fall into a mistake such as the multiplication of denominator by zero. The explanations of these prospective teachers may be due to the shortcomings in their content knowledge.

On the other hand, it was observed that there was only one prospective teacher who correctly explained how the formula was obtained and who associated this with the reason as to whether the memorization of the formula was made. The explanation of this prospective teacher is presented in Figure 24.

\begin{tabular}{|c|c|c|c|}
\hline & Gerekli & Gereksiz & Gerekçesinin Açıklaması \\
\hline$a \neq 0$ ise, $a^{0}=1$ dir. & Gerekli: & & 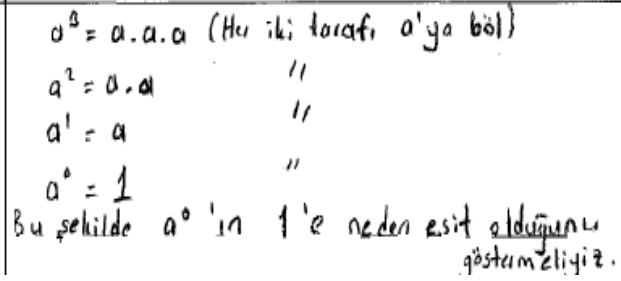 \\
\hline
\end{tabular}

Figure 24. Explanation of prospective teacher $T_{84}$ for the fifth question 
When Figure 24 is examined, it is observed that the prospective teacher could show that it is $\mathrm{a}^{0}=1$ at the student level by using the patterns but stated that the formula should be given to students instead of performing it every time. In this context, the reason of the prospective teacher was included in the correct group.

In conclusion, it was observed that some prospective teachers who thought that it was necessary to give the given formula to students could not make enough instructive explanations while explaining the reason why they thought so. Similarly, some prospective teachers also stated that it was necessary to give the given formula to students, but they could not make any instructive explanation about it and could not explain the logical reason underlying the formula. It was observed that some of these prospective teachers who thought that it was necessary to give the relevant rule to students stated that it was difficult to show the relevant rule to students and could not make any explanation about how the formula was obtained.

\subsection{Findings and Interpretation on the Sixth Question}

In the sixth question, prospective teachers were asked to explain whether it was necessary to give the formula given in the form of

$$
\frac{a^{m}}{a^{n}}=a^{m-n}
$$

with respect to division in exponential expressions to students as a new formula along with their reasons. The code, frequency and percentages related to the answers given by prospective teachers to the sixth question are presented in Table 7.

Table 7. Categories and Codes for the Sixth Question

\begin{tabular}{|l|c|c|c|c|c|c|c|c|c|c|c|c|}
\hline \multirow{2}{*}{ Codes } & \multicolumn{2}{|l|}{ Correctly } & \multicolumn{2}{l|}{$\begin{array}{l}\text { Partially } \\
\text { Correct A }\end{array}$} & \multicolumn{2}{|c|}{$\begin{array}{l}\text { Partially } \\
\text { Correct B }\end{array}$} & \multicolumn{2}{l|}{ Incorrect } & \multicolumn{2}{l|}{ Unexplained } & \multicolumn{2}{c|}{ Total } \\
\cline { 2 - 12 } & $\mathrm{f}$ & $\%$ & $\mathrm{f}$ & $\%$ & $\mathrm{f}$ & $\%$ & $\mathrm{f}$ & $\%$ & $\mathrm{f}$ & $\%$ & $\mathrm{f}$ & $\%$ \\
\hline $\begin{array}{l}\text { The necessity } \\
\text { reason of formula }\end{array}$ & 6 & $7 \%$ & - & - & 1 & $1 \%$ & 8 & $9 \%$ & 1 & $1 \%$ & 16 & $19 \%$ \\
\hline $\begin{array}{l}\text { The unnecessity } \\
\text { reason of formula }\end{array}$ & 47 & $56 \%$ & 1 & $1 \%$ & 2 & $2 \%$ & 17 & $20 \%$ & - & - & 67 & $80 \%$ \\
\hline $\begin{array}{l}\text { Undecided and } \\
\text { the reason }\end{array}$ & 1 & $1 \%$ & - & - & - & - & - & - & - & - & 1 & $1 \%$ \\
\hline
\end{tabular}

When Table 7 is examined, it is observed that while a total of $67(80 \%)$ prospective teachers argued that it was unnecessary to give the relevant formula to students, $16(19 \%)$ prospective teachers argued that it was necessary to give the relevant formula to students, and $1(1 \%)$ prospective teacher was undecided about whether the relevant formula should be given to students. When prospective teachers were asked for the reasons as to whether it was necessary to give this formula to students, while $54(64 \%)$ prospective teachers could correctly explain the reason why they thought so, $4(5 \%)$ prospective teachers partially explained it correctly, $25(30 \%)$ prospective teachers explained their reasons wrongly, and 1 $(1 \%)$ prospective teacher did not make any explanation.

When prospective teachers' explanations are examined, it is observed that the explanation of prospective teacher $\mathrm{T}_{18}$, who was undecided as to whether it was necessary to give the formula to students, to the sixth question is presented in Figure 25. 


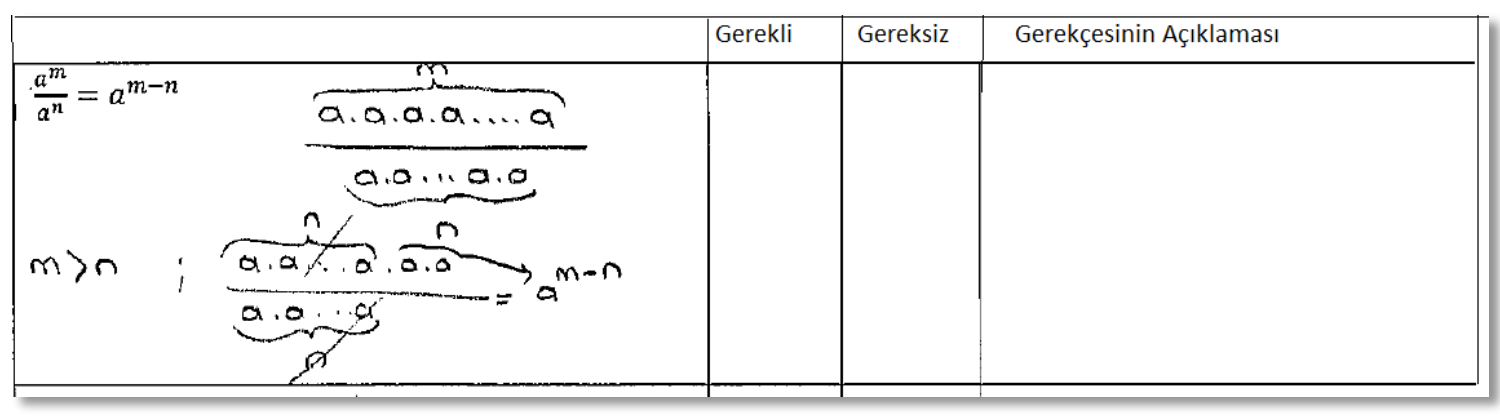

Figure 25. Explanation of prospective teacher $T_{18}$ for the sixth question

When Figure 25 was examined, it was observed that prospective teacher $\mathrm{T}_{18}$ could explain the logical reason of the relevant formula, in other words, could interpret the formula, but he did not make any explanation for the necessity of giving the relevant formula to students. On the other hand, most of the prospective teachers who thought that it was unnecessary to give the given formula to students argued that there was no need to make students memorize the given formula since they could obtain it based on their prior knowledge. The explanation of $\mathrm{T}_{5}$ among these prospective teachers is presented in Figure 26.

\begin{tabular}{|c|c|c|c|}
\hline & Gerekli & Gereksiz & Gerekçesinin Açıklaması \\
\hline$\frac{a^{m}}{a^{n}}=a^{m-n}$ & & $V$ & 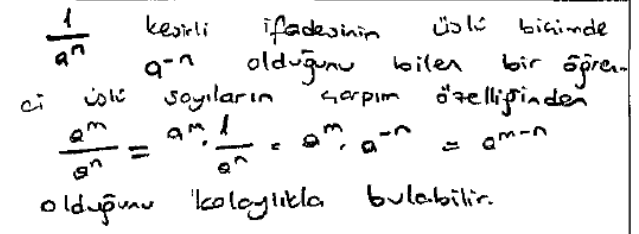 \\
\hline
\end{tabular}

${ }^{*} A$ student who knows that the expression $a^{n}$ is $a^{-n}$ in the exponential form can easily find that it is $a^{m-n}$ due to the multiplication property of exponential numbers.

Figure 26. Explanation of prospective teacher $T_{5}$ for the sixth question

When Figure 26 is examined, it is observed that prospective teacher $T_{5}$ stated that the given formula could be easily obtained based on the expression $\mathrm{a}^{-1}=\frac{1}{a}$ so it was unnecessary to give this formula to students as a new formula. It is observed that this explanation made by the prospective teacher is appropriate for students' level and is a correct explanation for the logical reason of the formula. Therefore, the reason of the prospective teacher was included in the correct code.

On the other hand, the vast majority of the prospective teachers who thought that it was necessary to give the given formula to students as a new formula argued that it was time-consuming to obtain the formula, therefore, it was necessary to make it memorized by students. The explanation of $\mathrm{T}_{62}$ among these prospective teachers is presented in Figure 27.

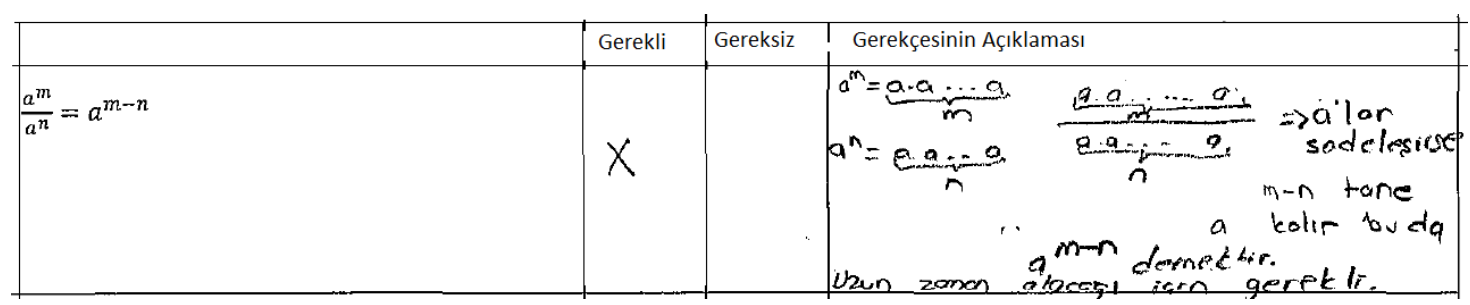

"If as are abbreviated, (m-n) numbers of a remain. Because this solution takes a long time, the formula should be given to students.

Figure 27. Explanation of prospective teacher $T_{62}$ for the sixth question 
When Figure 27 is examined, it can be said that prospective teacher $\mathrm{T}_{62}$ correctly explained the logical reason of the given formula and thus could interpret this formula. However, the prospective teacher stated that the operations performed while deducting the formula were time-consuming, and thus it was necessary to give this formula to students as a new formula. It was observed that there were also prospective teachers who followed a very similar path with prospective teacher $T_{62}$ in the process of interpreting the given formula but argued that the formula should not be given to students as a new formula, unlike prospective teacher $\mathrm{T}_{62}$. The explanation of $\mathrm{T}_{57}$ among these prospective teachers is presented in Figure 28.

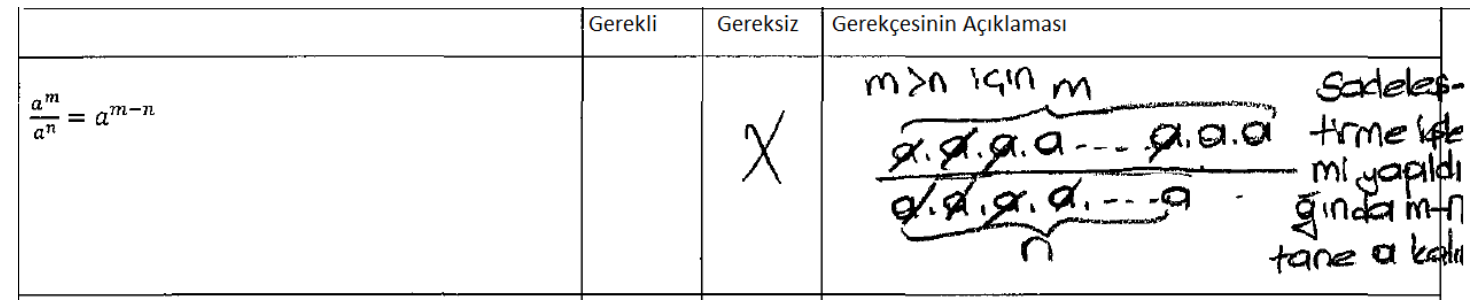

Figure 28. Explanation of prospective teacher $T_{57}$ for the sixth question

When Figure 28 was examined, it was observed that prospective teacher $\mathrm{T}_{57}$ could interpret the formula correctly and at the student level. Furthermore, this prospective teacher must have seen no harm for students to obtain the relevant formula by performing this operation every time, and he stated that he did not find it necessary to give this formula to students as a new formula. Unlike these prospective teachers, it was observed that there were also prospective teachers who did not make any educational explanation about how the relevant formula was obtained and argued that students should memorize the relevant formula since it was a basic formula. The explanation of $\mathrm{T}_{37}$ among these prospective teachers is presented in Figure 29.

\begin{tabular}{|c|c|c|c|}
\hline & Gerekli & Gereksiz & Gerekçesinin Açıklaması \\
\hline$\frac{a^{m}}{a^{n}}=a^{m-n}$ & & & 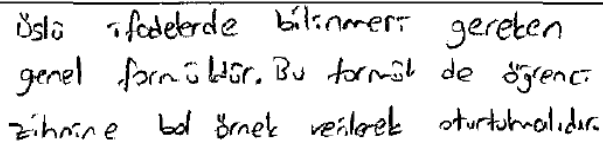 \\
\hline
\end{tabular}

*This formula is a general formula that should be known in exponentials. This formula needs to be placed in the mind of the student by solving plenty of examples.

Figure 29. Explanation of prospective teacher $T_{37}$ for the sixth question

When Figure 29 is examined, it is observed that the prospective teacher adopted a memorization logic and could not interpret the given formula. Furthermore, the fact that the prospective teacher stated that he would solve plenty of examples while teaching this formula to students does not mean anything other than memorizing for students. However, here it is expected from the prospective teacher to lay emphasis on how the formula is obtained, in other words, the logical reason behind it and to decide on whether the formula should be given to students based on this explanation. Therefore, the reason of this prospective teacher was included in the wrong code. Although some of the prospective teachers, whose reasons were included in the wrong group, explained the formula quite simply, they also stated that the formula should be given to students.

The explanation of $\mathrm{T}_{70}$ among these prospective teachers is presented in Figure 30. 


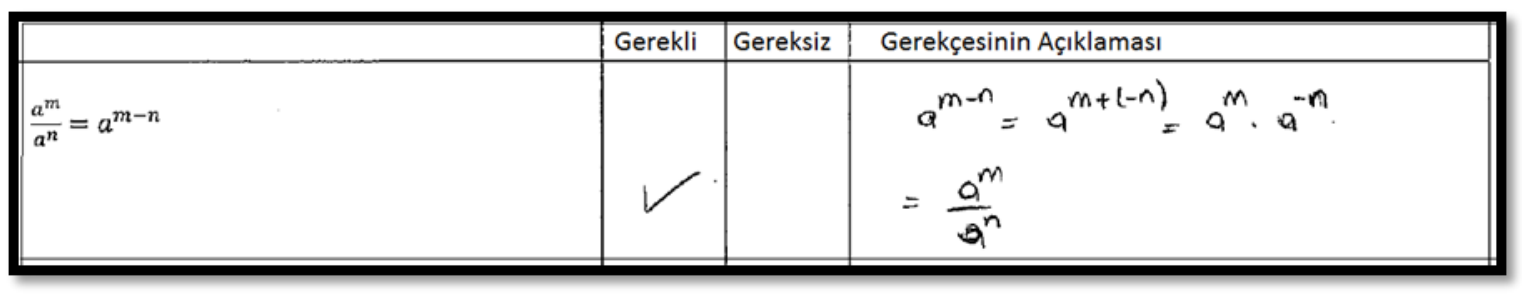

Figure 30. Explanation of prospective teacher $T_{70}$ for the sixth question

When Figure 30 was examined, it was observed that prospective teacher $\mathrm{T}_{70}$ could easily obtain and interpret the given formula using the properties of exponential expressions. Nevertheless, it is observed that this prospective teacher stated that it was necessary to make the relevant formula memorized by students. In this context, during the interview, the prospective teacher was asked for the reason why he preferred that it was necessary to make the formula memorized by students as a new formula although he reached the formula so easily. The explanations of the prospective teacher related to this subject are exactly given below.

"Teacher, everyone cannot understand this explanation because it is a little bit algebraic. Therefore, those who cannot understand it should memorize it, in other words, they should know it. If they forget, I would tell how it is obtained so that they remember that it is found in this way."

When the prospective teacher's explanation is examined, it is observed that he stated that he would express the meaning of the formula to students, but students who cannot understand this should know it by heart. However, it is obvious that students who have fully learned exponential expressions and their properties will not have difficulty in learning the meaning of this formula. Based on these statements, it does not make sense to teach this formula as if it is a new formula.

In conclusion, it can be said that most prospective teachers' explanations on how the formula related to division in exponential expressions given in the sixth question is obtained and on its meaning are sufficient. In this context, it was observed that prospective teachers usually explained the meaning of the formula by using the operational properties related to multiplication and exponential expressions and mostly $(80 \%)$ stated that it was unnecessary to give the formula to students as a new formula.

\section{Conclusion, Discussion and Suggestions}

In this section, the results of the study will be addressed in the light of the results obtained, literature discussion will be made, and various suggestions will be put forward.

Most of the prospective teachers (63) could correctly explain the logical reason behind the formula that can be obtained simply by the digit analysis and stated that it was unnecessary to give this formula to students as a new formula by arguing that it was easy to obtain it. Moreover, the prospective teachers who stated that the relevant formula should be given to students (10) attempted to explain the logic of the formula by applying it or giving value and indicated that it was necessary to give the formula in terms of practicality. It was observed that these prospective teachers further complicated the formula that could be found very simply by the digit analysis and stated that the formula should be memorized by students because of this difficulty.

Furthermore, in the second question related to identities, it was observed that 56 prospective teachers could correctly explain the logical reason behind the formula. Prospective teachers usually benefited from the square of the sum of two terms while explaining the reason underlying this formula. Most of the prospective teachers who put forward this reason suggested that it was unnecessary to give the formula to students as a new formula. Nevertheless, prospective teachers whose number cannot be underestimated (38\%) stated it was necessary to give the formula to students as a new formula. This is consistent with Jarrah's (2013) conclusion that most teachers believe that the best way to learn mathematics is to memorize all formulae. However, to make students memorize the formula that can be simply found by knowing the square of the sum of two terms will further complicate the subject in terms of students because the formula obtained from the square of the sum of three terms is both a long and 
complicated expression. This may also cause students to have difficulty and to develop a negative prejudice against mathematics. In the third question related to identities, 68 prospective teachers stated that the formula should be directly given to students while 13 prospective teachers indicated that it was unnecessary to give the formula to students as a new formula. When these prospective teachers were asked for the reasons for their statements, it was observed that no prospective teacher could provide a correct explanation. From this point of view, it can be said that prospective teachers cannot interpret the formula, and therefore they will teach the formulae related to identities to students by heart without interpretation. However, the subject of identities is not a subject that can be learned or taught by heart. With respect to this, Akın (2007) stated in his study that there are dozens of identity formulae and that students will have difficulty in remembering the information they have memorized unless they learn these formulae meaningfully.

When the answers given by the prospective teachers to the fourth question were analyzed, it was observed that few (15) prospective teachers could correctly explain the logic of the rule $0 !=1$. The prospective teachers who correctly explained the logical reason of this rule usually benefited from the properties of the concept of the factorial and indicated that it was necessary to give it to students as a new formula provided that they showed the logic of this rule. The vast majority of the prospective teachers (60) described this rule as an acceptance and stated that it was necessary to directly make the formula memorized by students by making an explanation containing only information based on memorization without any logical basis. This result is consistent with the studies in the literature (Dellalbaşı \& Soylu, 2012; Gökkurt, Şahin, \& Soylu, 2015; Tan Şişman \& Aksu, 2009; Toluk Uçar, 2011). Based on this, it can be concluded that these prospective teachers will adopt the method of teaching by rules while teaching this subject to their students. In this regard, Pesen (2003, pp.40) indicates that it is not a good teaching method to start giving a concept with rules and that it is difficult to remember a concept that is learned with rules when it is forgotten.

When prospective teachers' explanations for the formula $a^{0}=1$ given with respect to exponential expressions were examined, it was observed that 40 prospective teachers argued that it was unnecessary to give this formula to students as a new formula but only 1 prospective teacher correctly explained the reason why he thought so. On the other hand, 43 prospective teachers argued that it was necessary to give this formula to students; however, none of these prospective teachers could correctly explain the reason why they thought so. Prospective teachers mostly used the properties of division in exponential expressions and number patterns while explaining the logic of the given formula, and from this point of view, they stated that it was important to give the relevant formula to students in terms of practicality and avoiding the waste of time. However, with respect to this, Duatepe Paksu (2013) stated that it was necessary to include the activities in which students themselves reach the operational information such as rules and formulae instead of giving the rules related to exponential numbers readily.

In the sixth question given with respect to division in exponential expressions, 16 prospective teachers argued that it was unnecessary to give the formula as a new formula, and only 6 of these prospective teachers could correctly explain the reason why they thought so. 67 prospective teachers argued that it was unnecessary to give the relevant formula to students while 47 prospective teachers correctly explained the reason why they thought so. However, prospective teachers did not make any explanation for the definition or the property of the concept of exponential expressions while expressing the logical reason of the given formula and obtained the formula by using the inverse of a number according to multiplication. Consequently, it was observed that prospective teachers mostly explained the formulae given with respect to exponential expressions by benefiting from the operational properties of exponential expressions and made correct explanations for the derivation of the formula even though they did not make too much explanation for the definition or logic of exponential expressions. This result is consistent with the study of Dellalbaşı and Soylu (2012).

As a result of the study carried out, it was observed that the prospective teachers did not examine the logic of the formulae and did not think too much about from where the formulae were obtained. Therefore, it is necessary to raise awareness of the reasons underlying the formulae in prospective teachers by providing the environments that improve prospective teachers' interpretation and reasoning skills on the formulae used in major area courses given during undergraduate education because the fact 
that prospective teachers comprehend the logic of the given formulae may be influential on the teaching they will perform. It is possible to focus on the studies concerning this issue in mathematics education. This study was conducted with prospective teachers. A similar study can be conducted with teachers, and the results can be compared. Furthermore, teachers and prospective teachers can improve themselves by learning how any formula the logical reason or meaning of which is not known by them is interpreted or can offer new solution proposals by examining this study.

\section{References}

[1] Akın, M.F. (2007). The effects of a constructive learning approach on learning success in the teaching of identities. Unpublished master thesis, Dicle University, Institute of Science, Diyarbakır.

[2] Albayrak, M., Işık, C., \& İpek, A.S. (2005). Self-fulfilment on learning math. Kastamonu Educational Journal 13,1, 129-138.

[3] Arslan Kilcan, S. (2006). The levels of elementary mathematıcs teachers' conceptual knowledge of the division with fractions. Unpublished master thesis, University of Abant İzzet Baysal, Bolu City.

[4] Ball, D. L., Thames, M.H., \& Phelps, G.(2008). Content knowledge for teaching: What makes it special? Journal of Teacher Education, 59, 5, 389-407.

[5] Barrantes, M., ve Blanco, L. J. (2006). A study of prospective primary teachers' conceptions of teaching and learning school geometry. Journal of Mathematics Teacher Education, 9,5, 411436.

[6] Battista, M. T., ve Clements, D. H. (1996). Students' understanding of three-dimensional rectangular arrays of cubes. Journal for Research in Mathematics Education, 27, 3, 258-292.

[7] Baykul, Y. (2014). Secondary school math teaching (5-8 class) (2th press) Ankara: Pegem Publishing.

[8] Bonotto, C. (2003). About students' understanding and learning of the concept of surface area. Learning and Teaching measurement, 157-167.

[9] Dellalbaş1, O., \& Soylu, Y.(2012). The effect of jıgsaw and group research techniques on the academic success of 8th grade students in mathematics courses. The Journal of Academic Social Science Studies, 5, 7, 229-245.

[10] Doğan, A. (2001). A research on misconceptions and mistakes of the students and their attitudes towards the trigonometry subjects which are teaching in the high schools. Unpublished dissertation thesis, Selçuk University, Konya.

[11] Duatepe Paksu, A.(2013). Üslü ve köklü sayılar konularındaki öğrenme güçlükleri. Özmantar, M. F.,Bingölbali, E. ve Akkoç, H. (Eds): Matematiksel kavram yanılgıları ve çözüm önerileri. Pegem Akademi, Ankara, 24-27.

[12] Fuys, D., Geddes, D. \& Tischler, R. (1988). The van Hiele model of thinking in geometry among adolescents. Journal for Research in Mathematics Education, 3, 1-198.

[13] Gökkurt, B. (2014). An examination of secondary school mathematics teachers' pedagogical content knowledge on geometric shapes. Unpublished dissertation thesis, Atatürk University, Erzurum.

[14] Gökkurt, B., Şahin, Ö., Erdem, E., Başıüyük, K. \& Soylu, Y. (2016). Investigation of pedagogical content knowledge of middle school prospective mathematics teachers on the cone topic in terms of some components. Journal of Cognitive and Education Research, 1, 1, 18-40. 
[15] Gökkurt, B., Şahin, Ö., Soylu, Y. \& Doğan, Y. (2015). Preservice teachers' pedagogical content knowledge regarding student mistakes on the subject of geometric shapes. Elementary Education Online, 14, 1, 55-71.

[16] Huang, H. M. E. ve Witz, K. G. (2011). Developing children's conceptual understanding of area measurement: A curriculum and teaching experiment. Learning and instruction, 21, 1, 1-13.

[17] Işıksal, M., Kurt, G., Doğan, O. \& Çakıroğlu, E. (2007). Epistemological conceptions of preservice elementary mathematics teachers: effects of university and grade level, Elementary Education Online, 6, 2, 313-321.

[18] Jarrah, A.M. (2013). Investigation of jordanian pre-service teachers' beliefs about learning and teaching of mathematics. Unpublished doctoral dissertation, University of Missouri, Kansas City.

[19] Kamii, C.\& Kysh, J. (2006). The difficulty of "length $\times$ width": Is a square the unit of measurement?. The Journal of Mathematical Behavior, 25, 2, 105-115.

[20] Koçak M. \& Soylu, Y.(2017). Analysis of Pre-service Mathematics Teachers' Teaching Strategy Knowledge of Geometric Formulas. Universal Journal of Educational Research,5, 3, 297-315. DOI: 10.13189/ujer.2017.050302.

[21] Kohlbacher, F. (2006). The use of qualitative content analysis in case study research. Forum: Qualitative Social Research 7, 1, 21.

[22] Ministry of National Education[MNE] (2013). Secondary school mathematics lesson (5, 6, 7 and 8 classes) teaching curriculum. Ankara: Board of Education and Discipline

[23] Nasibov, F., \& Kaçar, A. (2005). About math and teaching math. Kastamonu Educational Journal, 13, 2, 339-346.

[24] Olkun, S. (2001). Let's help students to understand the volume formula. Educational Sciences: Theory \& Practice, 1, 1, 181-190.

[25] Olkun, S. (2003). When does the volume formula make sense to students?. Hacettepe University Journal of Education, 25, 160-165.

[26] Olkun, S., Çelebi, Ö., Fidan, E., Engin, Ö. \& Gökgün, C. (2014). The meaning of unit square and area formula for turkish students. Hacettepe University Journal of Education, 29, 1, 180-195.

[27] Pesen, C. (2003). Mathematics teaching for education faculties and primary teachers. Ankara:Nobel Publising.

[28] Philipp, R. A., Thanheiser, E., \& Clement, L. (2002). The role of a children's mathematical thinking experience in the preparation of prospective elementary school teachers. International Journal of Educational Research, 37, 2, 195-210.

[29] Tan Şişman, G., \& Aksu, M. (2009). Seventh grade students' success on the topics of area and perimeter. Elementary Education Online, 8, 1, 243-253.

[30] Toluk Uçar, Z. (2011). Preservice teachers' pedagogical content knowledge: instructional explanations. Turkish Journal of Computer and Mathematics Education, 2, 2, 87-102.

[31] Van De Walle, J.A., Karp, K.S., \& Bay-Williams, J.M. (2014). Elementary and middle school mathematics teaching developmentally (7th edition). S.Durmuş(Eds.). Ankara: Nobel Publising.

[32] Yıldırım, A., \& Şimşek, H. (2013). Qualitive research methods in the social sciences. (8th edition). Ankara: Seçkin Publising. 


\section{Authors}

Meltem Koçak, Atatürk University, Erzurum/Turkey, meltemm.kocak@ gmail.com

Yasin Soylu, Atatürk University, Erzurum/Turkey, yasinsoylu@gmail.com 